\title{
The Balance between the Rights and Duties of Holder of Negotiable Instrument; Existent Order and Ideal Balancing
}

\author{
Ahmad Esfandiari ${ }^{1 *}$ Gholamali Seifi Zinab $^{2}$
}

Received:
18 Jul 2020
Revised:
11 Aug 2020
Accepted:
23 Aug 2020
Available Online:
01 Oct 2020

Keywords:

Balance,

Rights,

Duties,

Holder,

Negotiable

Instrument.
Background and Aim: The aim of this research is a study of a balance between the rights and duties of holder of a negotiable instrument in Iranian negotiable instruments law and recognition of strength and weakness points and lacks in existent provisions.

Materials and Methods: This is a descriptive Study.

Ethical Considerations: All ethical considerations as well as authenticity of the texts have been observed.

Findings: The legislator in Iranian negotiable instruments law tried to create a balance between the rights and duties of persons entered in negotiable instrument and in accordance with that in opposing the rights such as collective liability of signers, possibility of demanding vast conservatory injunction etc. that give to the holder in order to strengthen and accelerate in payment the sum inserted, imposed to him duties such as delivering of instrument for acceptance and payment to drawer.

Conclusion: Iranian negotiable instruments law have not reached success to Balance Between The Rights And Duties of Holder of Negotiable Instrument; because in one hand, in spite of doing legal duties, there didn't given a suitable right to the holder in such a way that obligor or liable to instrument can or by invoking to see of, weaken his position and in other hand, in some cases, created for him unilateral rights.

\footnotetext{
1* Assistant Professor, Department of Private Law, Faculty of Humanity Science, Islamic Azad University, Sari Branch, Sari, Iran. (Corresponding Author)

Email: Esfandiari_ahmad@yahoo.com_Phone: +989927566180

${ }^{2}$ Assistant Professor, Department of Private Law, Faculty of Law, Shahid Beheshti University, Tehran, Iran.
}

Please Cite This Article As: Esfandiari, A \& Sefi Zinab, Gh (2020). "The Balance between the Rights and Duties of Holder of Negotiable Instrument; Existent Order and Ideal Balancing”. Interdisciplinary Legal Research, 1 (3): 64-83. 
مقاله يزوهشى

(صفحات (ص)

\section{تعادل حقوق و تكاليف دارندهُ سند تجارى؛ نظم موجود و توازن مطلوب

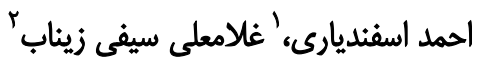

(. استاديار، گروه حقوق خصوصى، دانشكده علوم انسانى، دانشخاه آزاد اسلامى، واحد سارى، سارى، ايران. (نويسنده مسؤول)

Email: Esfandiari_ahmad@yahoo.com

ז. استاديار، گروه حقوق خصوصى، دانشكده حقوق، دانشعاه شهيد بهشتى، تهران، ايران.

دريافت:

زمينه و هدف: هدف از انجام اين تحقيق، بررسى تعادل ميان حقوق و تكاليف دارنده سند تجارتى در حقوق اسناد تجارى ايران و شناسايى نقاط قوت و ضعف و خلأهاى مقررات موجود است. مواد و روشها: روش تحقيق در نكارش اين مقاله به صورت توصيفى است.

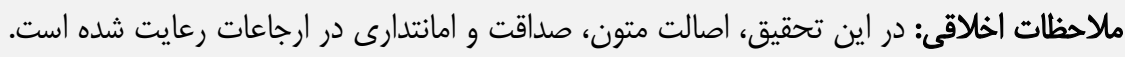

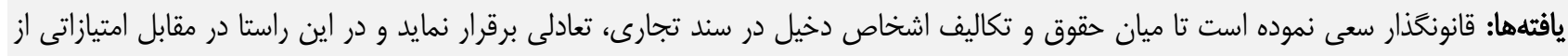

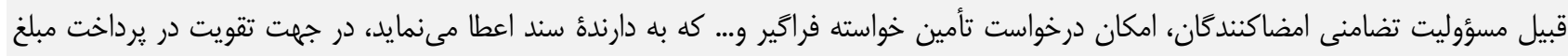

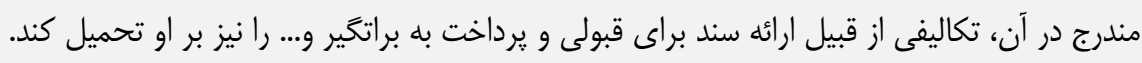

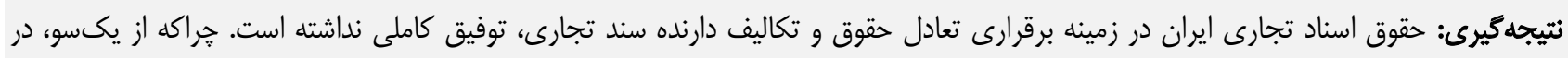

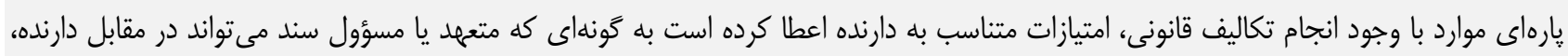

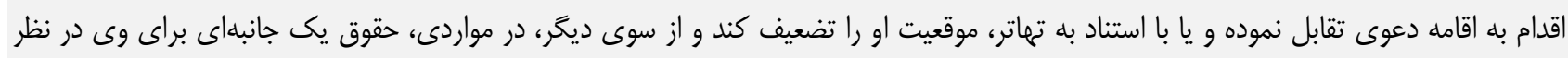
كر فته شده است. كلمات كليدى: توازن، حقوق، تكاليف، دارنده، سند تجارى. 
دارنده بدون انجام تكليف مشخصى، حقوق يكجانبه و ممتازى به دست آورده است. اين تحقيق به دنبال توجيهيذيرى قواعد حقوق اسناد تجارى بر اساس تعادل ميان حقوق و تكاليف

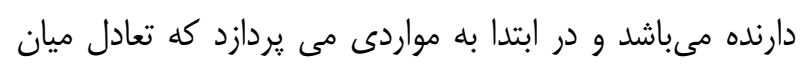

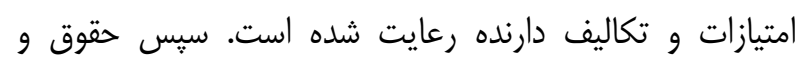
امتيازات ضرورى كه علىرغم انجام تكاليف قانونى از وى دريغ شده است، بررسى مىشود و سرانجام امتيازات و حقوق يكسويهاى كه با دست و دل بازى به دارنده اعطا گرديده است مورد مداقه قرار خواهد كرفت. r- روش تحقيق: روش اين تحقيق بصورت توصيفى- تحليلى

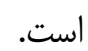

بحث و نظر ا - تعادل ميان حقوق و تكاليف دارنده

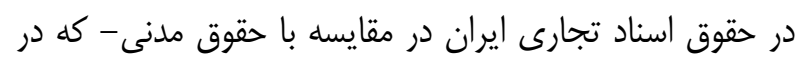

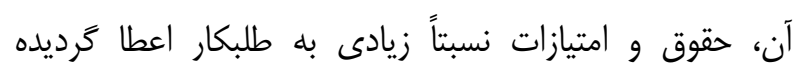
است- قانونحذار در بسيارى از موارد، نه تنها حقوق و امتيازات يكجانبهاى به دارنده سند، نداده است بلكه تلاش نموده است له

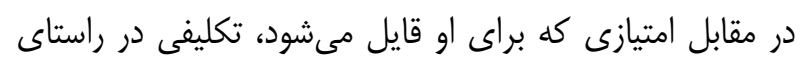
تسريع در يرداخت وجه سند بر او تحميل نمايد يا در إزاى انجام

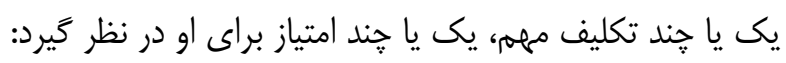
1-1- لزوم مطالبه قبولى و انجام اعتراض نكول: بند بـ ماده سזr قانون تجارت، تعيين نام تأديهكننده وجه برات يعنى براتخير را يكى از شرايط شكلى برات، معرفى نموده است. نوشتن نام براتخير در برات به تنهايى براى او تعهدى، ايجاد

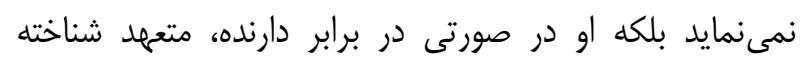

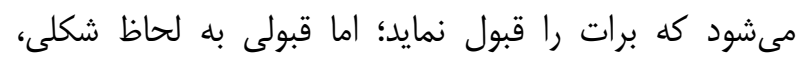

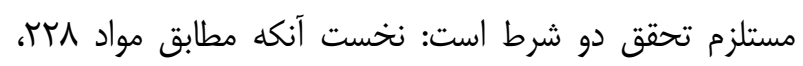

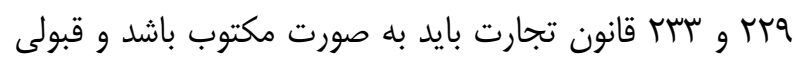

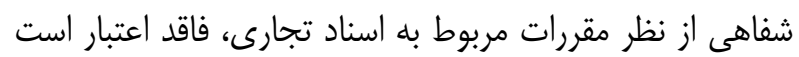
و دوم آنكه از آنجايى كه تمام حقوق دارندهُ سند تجارى از خود سند، ناشى مى شود، قبولى بايد در خود برات منعكس گرددد.

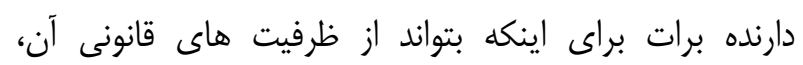

مقدمه

1- بيان موضوع: يكى از عواملى كه مىتواند موفقيت هر نهاد

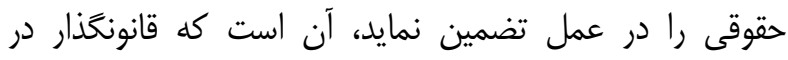

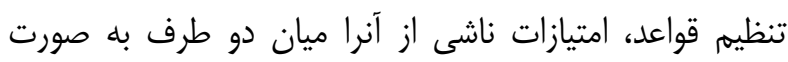

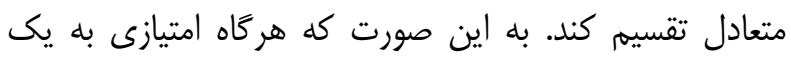
طرف مىدهد، براى طرف مقابل، هم امتيازى قايل شود. در غير

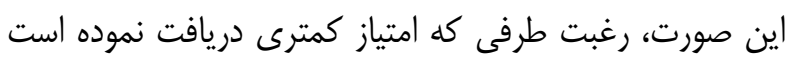
به ورود در اين رابطه به شدت كاهش مىيابد و كاركرد نهاد حقوقى مورد نظر را خنثى مىسازد. علاوه بر اين، تقسيم

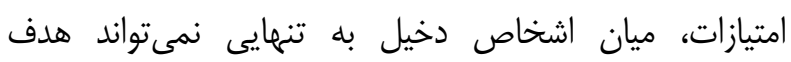

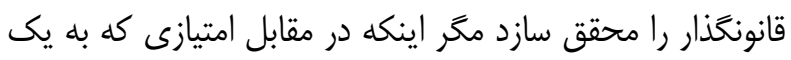
طرف مىدهد، تكليفى براى او در نظر كيرد. ارزيابى درباره كاركرد مناسب اسناد تجارى در تنظيم روابط ميان اشخاص وارد و ذىنفع در سند نيز در همين خاجوب، قابل انجام است.

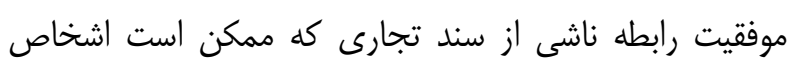

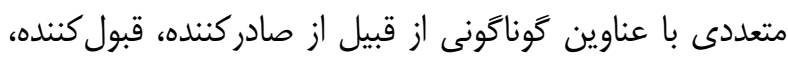
ظهرنويس و ضامن، حسب مورد، ايفاى نقش نمايند نيز در كروى تقسيم متعادل حقوق و تكاليف ميان اطراف آن است. با اينكه درباره حقوق اسناد تجارى، كتابها و مقالاتى نوشته

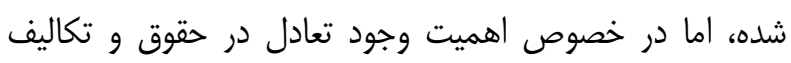
اطراف سند و از جمله تعادل حقوق و تكاليف دارنده، يزوهشى إنى انجام نشده است. از آنجايى كه در حقوق اسناد تجارى، دارنده

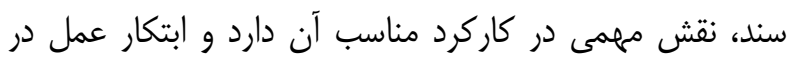

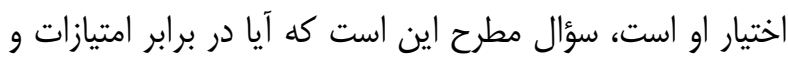

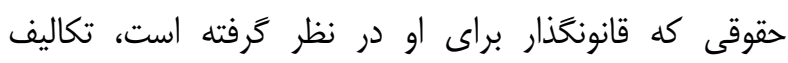

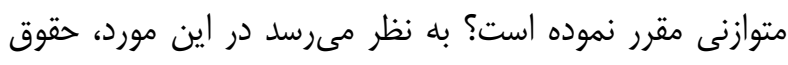
اسناد تجارى ايران، نتوانسته است توفيق كاملى داشته باشد. بررسى مقررات مربوط نشان مىدهد كه اخرجه در يارهاى موارد در قبال انجام تكاليف قانونى، امتيازات متناسبى به دارنده اعطا مران كرديده است، در برخى موارد متعهد سند مىتواند در مقابل

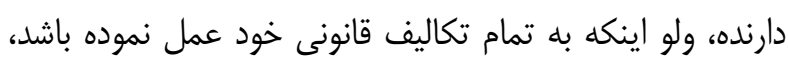
با انجام اقدامات ايذايى، خاصيت ذاتى سند را بـىاثر سازد و

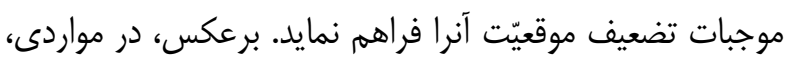


كند.ه منظور از ماده فوق آن نيست كه هركاه دارنده در روز

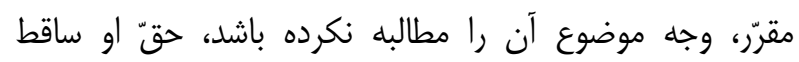
مىشود زيرا دارنده برات مىتواند تا ده روز از تاريخ سررسيد نيز وجه آنرا به براتخير ارائه دهد. بنابراين ماده مذكور، صرفأ مطالبه

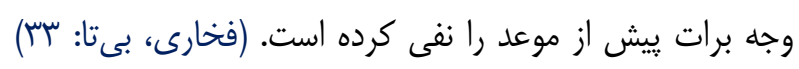

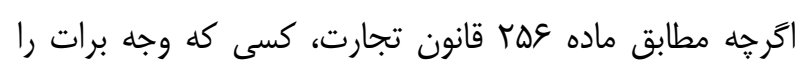
قبل از سررسيد بيردازد در مقابل اشخاصى كه نسبت به وجه ماده

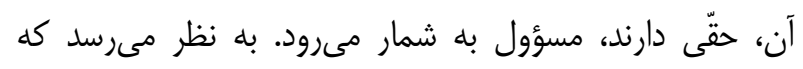

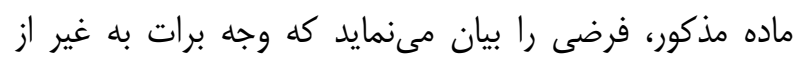

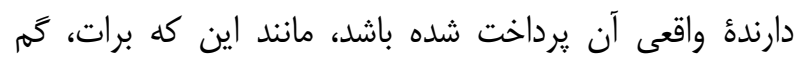

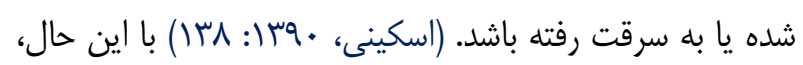

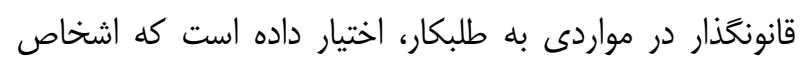

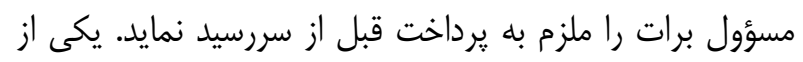

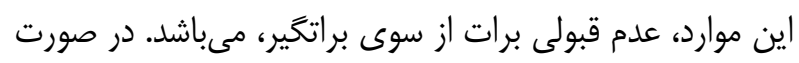

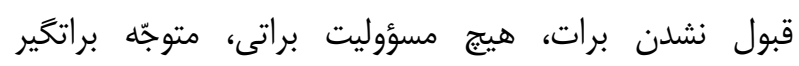

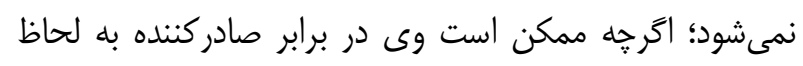

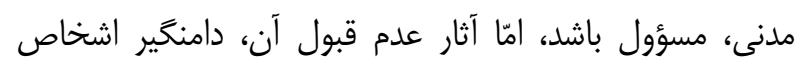

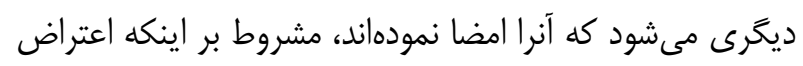
نكول انجام شده باشد. علّت اين امر، آن است كه امضاكنندكان

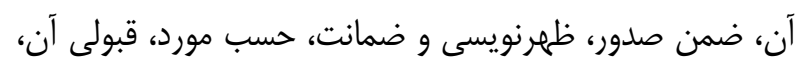

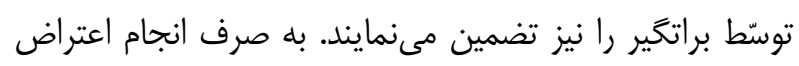

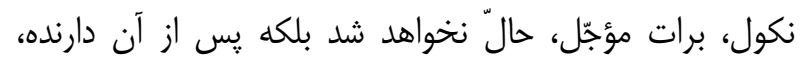

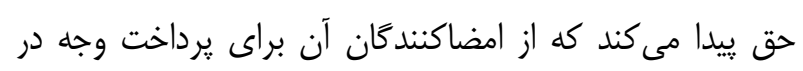

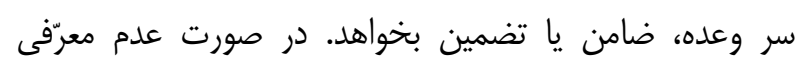

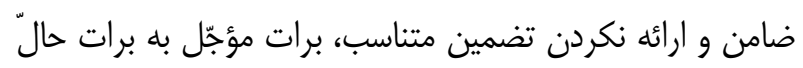

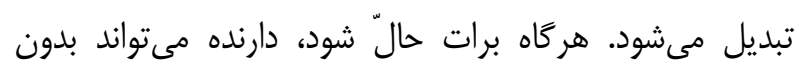

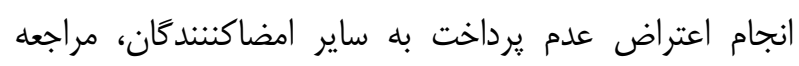
نموده و از تمام حقوقى كه قانون براى برات اعتراض شده مقرّر

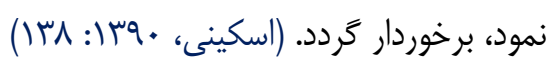

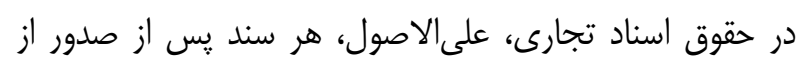

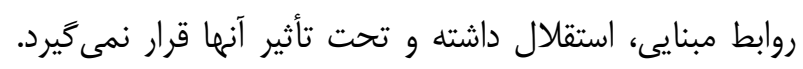

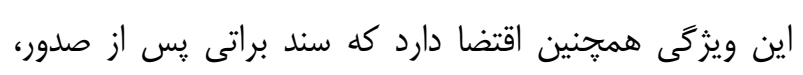

استفاده نمايد، ناجار است، آنرا به براتخير، ارائه و قبولى را مطالبه

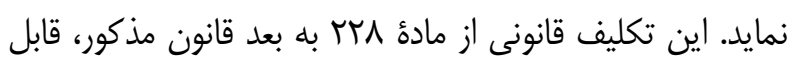
استباط است. در صورت نوشتن قبولى، او متعهد اصلى يرداخت

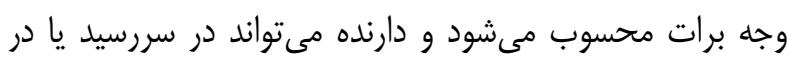

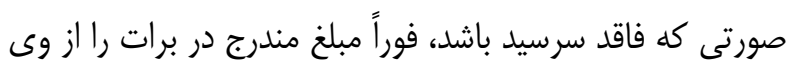
مطالبه نمايد. ارائه برات، براتخير را ملزم به نوشتن قبولى روى آن نمىنمايد،

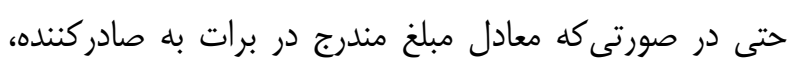

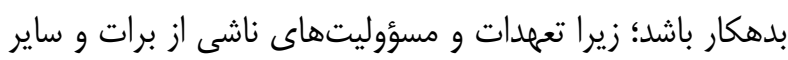

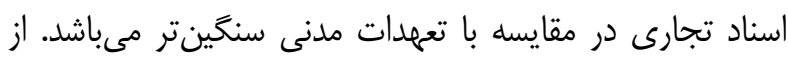

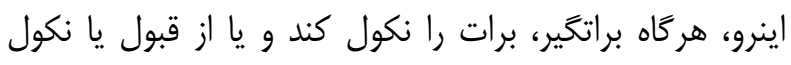

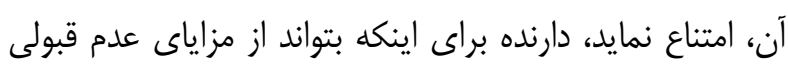

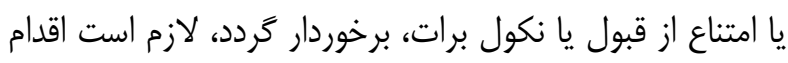
به اعتراض نكول كند. اعتراض نكول يعنى تأييد رسمى نكول.

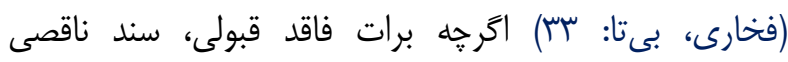
محسوب مى كردد، قانونگذار نه تنها در مقابل اقدامات دارنده

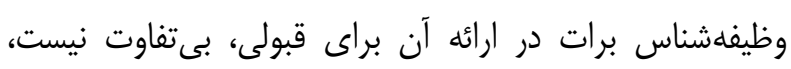
بلكه از اين جهت حقوقى براى وى در نظر گرفته است:

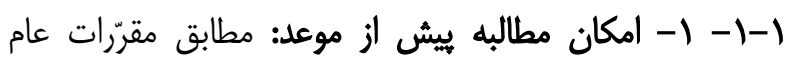

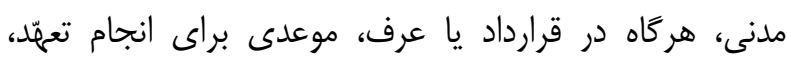

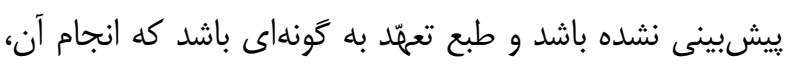

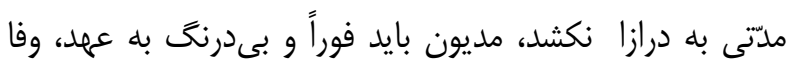

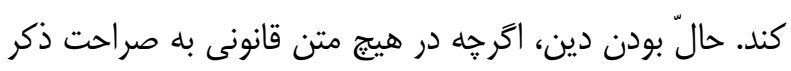

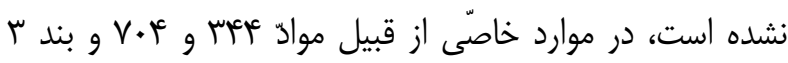

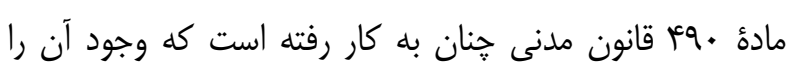

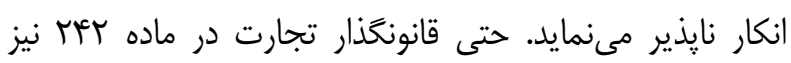

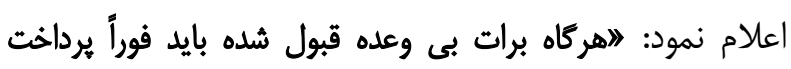

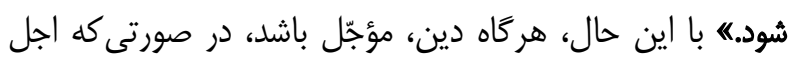
به نفع بدهكار يا طرفين باشد، طلبكار نمىتواند يرداخت آنرا ييش از موعد درخواست كند و او را به يرداخت آن، ملزم سازد.

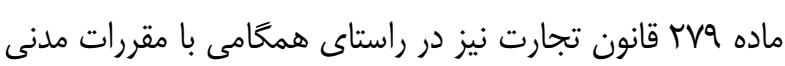

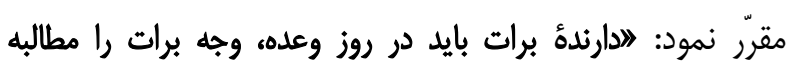


قانون تجارت، هر كاه براتخير نه ضامن معرفى كند و نه تضمين

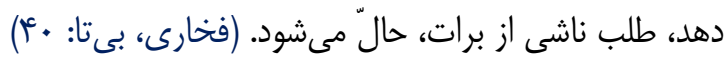
1-1-Y- امكان قبولى ثالث: با نكول برات از سوى براتخير به اعتبار صادركننده و ظهرنوسان، لطمه وارد مىشود و امكان

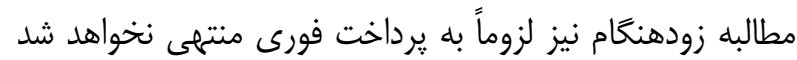
و جهبسا ممكن است، اشخاص مذكور به دليل عدم امكان

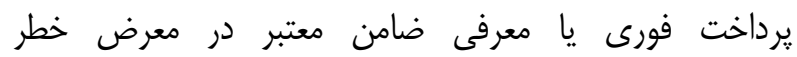
ورشكستكى قرار گيرند و دارنده نتواند به تمام حقوق خود برسد. به منظور اجتناب از جنين وضعيتى، نهاد حقوقى قبولى شخص ثالث يِيشينى شده است. در برخى نظامهاى حقوقى در صورت نكول برات توسط براتخير، دارنده، بايد برات را براى اخذ قبولى به شخص ثالثى ارائه نمايد تا او قبولى رادر خود برات قيد كند

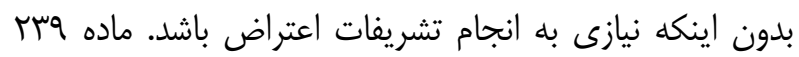

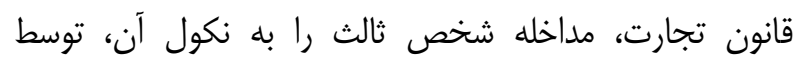
براتكير و انجام تشريفات اعتراض از سوى دارنده، موكول نمود. اصرار قانونگذار بر انجام اعتراض نكول تا جايى است كه

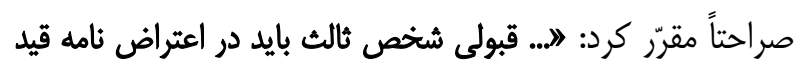
شده و به امضاى او برسد.

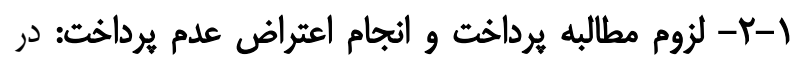

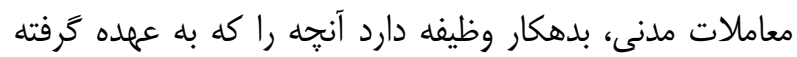

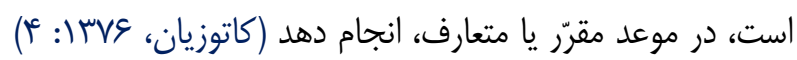

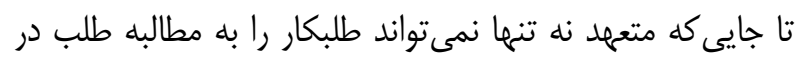
سررسيد، مجبور كند بلكه مطابق ماده سrT قانون مدنى در صورتى كه صاحب حق از قبول آن، امتناع كند، متعمّد بايد آن را مان ماند به تصرف حاكم يا قائم مقام او دهد. در اين صورت، طلبكار-

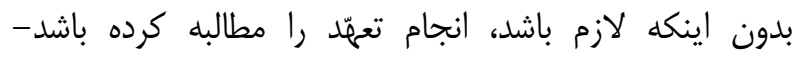

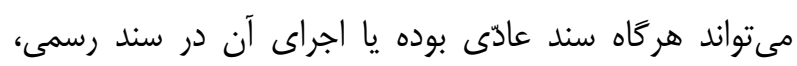
منوط به اجراى شرطى شده باشد كه نياز به رسيدگى و قضاوت

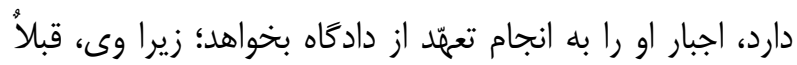
هنگام انشاء عقد و انجام توافق در مورد موعد، انجام تعهد را درخواست كرده و درخواست بعدى اجراى قرارداد، جيزى جز

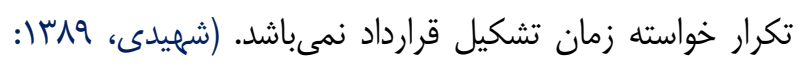

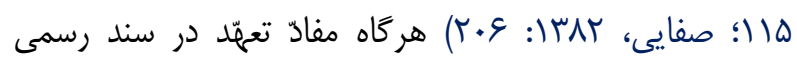

تحت تأثير روابط سندى اطراف آن در غير از سند مورد نظر نيز

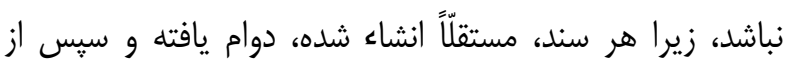
كردش خارج مىشود و به عبارت ديخر، هر كاه دارندة برات در سر وعده به براتخير مراجعه نموده و در صورت عدم يرداخت و انجام اعتراض در مواعد مقرّ، حق دارد به ساير مسؤولان

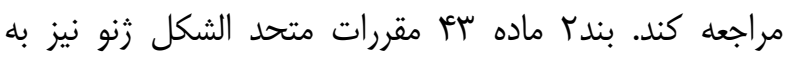
دارندهُ سند حق داده است تا در صورت حصول توقّف در مرد يرداختهاى براتخير، مبلغ مندرج در سند را قبل از سررسيد، مطالبه نمايد. ماده مبr قانون تجارت نيز در مواردى كه براتخير،

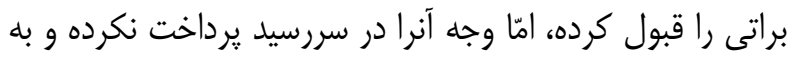

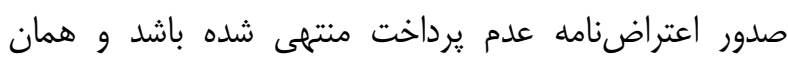
براتخير، برات دوّمى را قبول كرده كه سررسيد آن هنوز فرا نرسيده باشد، به دارندة برات دوّم حق داد تا از براتخير، ضامن بخواهد يا از او درخواست كند كه يرداخت وجه مندرج در آنرا به

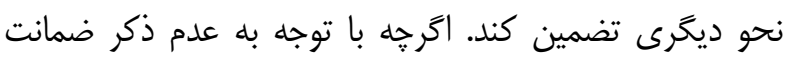
اجراى عدم معرّفى ضامن يا دادن تضمين برداخت در سررسيد

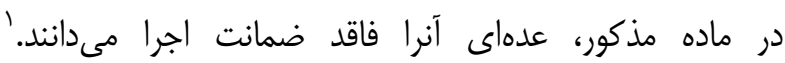

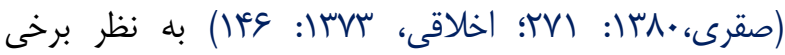
نويسندًان حقوق تجارت با توجّه به وحدت ملاك ماده УسT

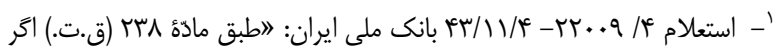

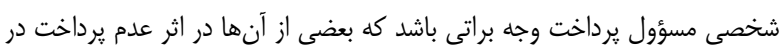

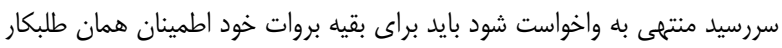

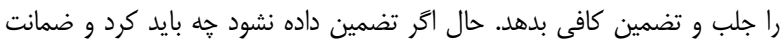

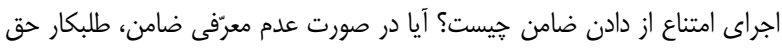

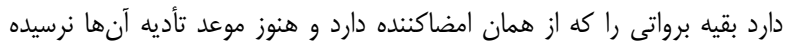

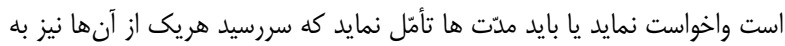

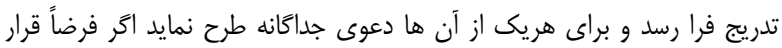

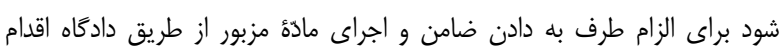

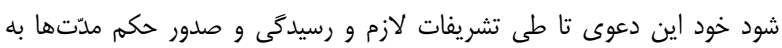

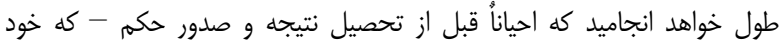

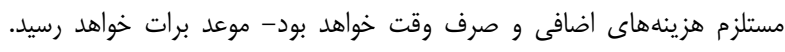

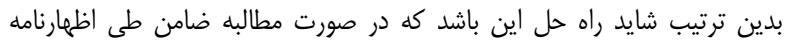

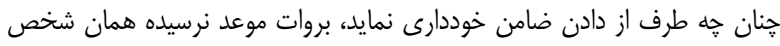

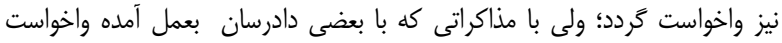

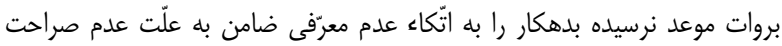

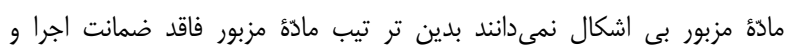
غيرعملى خواهد ماند.... 
مدّت مورد نظر، سند را جهت دريافت وجه به براتخير، متعمّد

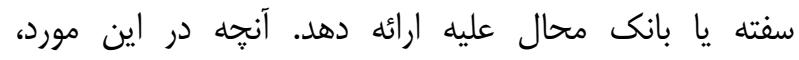
موضوعيّت دارد اين است كه احراز و تسجيل مطالبه وجه سند و به

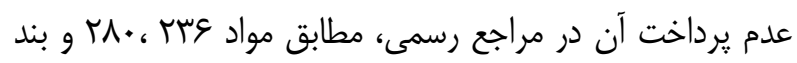

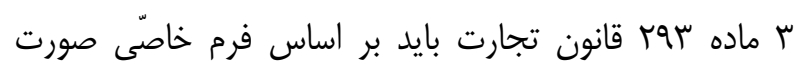
يذيرد كه 》اعتراضنامه يا يروتسته ناميده مىشود. جِنين

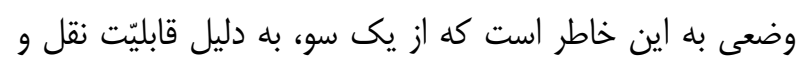

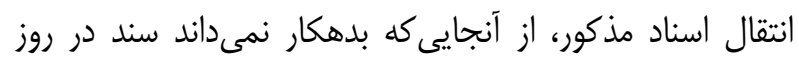

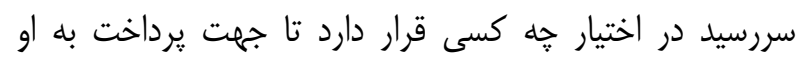
رجوع كند، براتخير، متعمّد سفته و ... الزامى به يِيدا كردن او

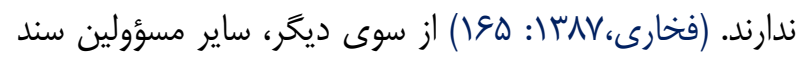

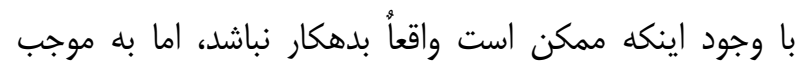

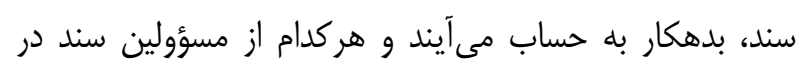

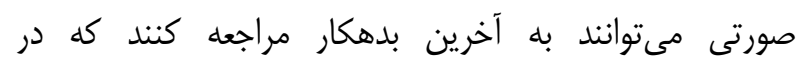
مهلتهاى قانونى مقرّر به وظايف خود عمل نمايند. دارنده سند مكلّف است مراجعه خود به براتخير يا متعمّد اصلى سند، حسب

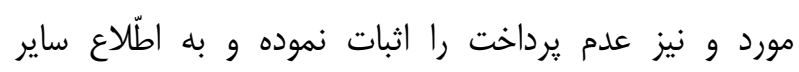
مسؤولين برساند. ماده وr ق قانون تجارت دارنده را مكلف نمود روز وعده، وجه برات را مطالبه نمايد و در صورت امتناع براتخير از پرداخت، ظرف ده روز، اقدام به اعتراض عدم يرداخت نمايد.

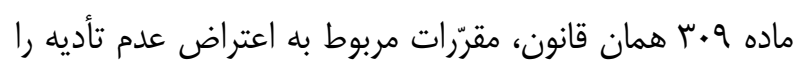

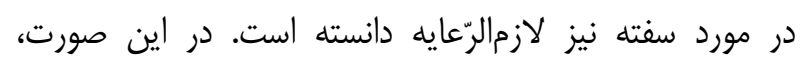

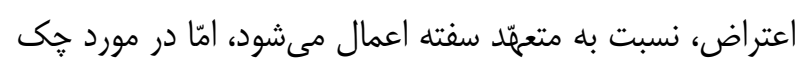
احرجه قسمت اخير ماده أIاس قانون تجارت مقرّرات اين قانون از ضمانت صادركننده و ظهرنويسها و اعتراض و... راجع به فيه بروات را شامل خك هم نمود، اما بر اساس مواد عأ و ه قانون

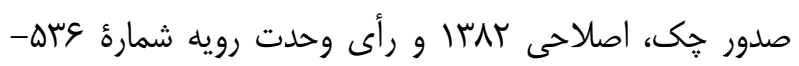

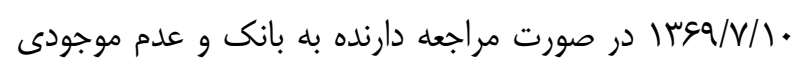
يا كسرى موجودى، بانك، مكلف است كه حسب مورد،

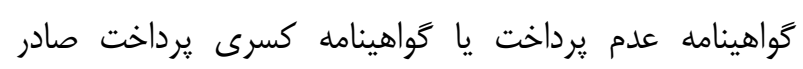

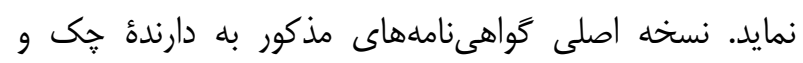
نسخه دوم به نشانى صادركننده ارسال مىشود. در اهميت
آمده باشد و اجراى آن، منوط به احراز واقعه يا شرطى از سوى دادكاه نباشد، طلبكار مىتواند از دفتر تنظيم كننده سند يا اداره

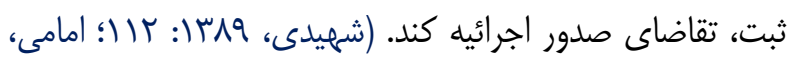

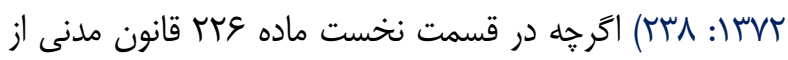
مطالبه خسارت (و نه اجراى اجبارى تعمّد) سخن به ميان آمده

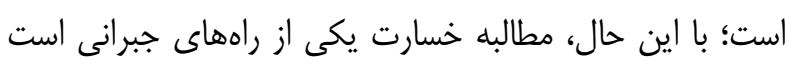

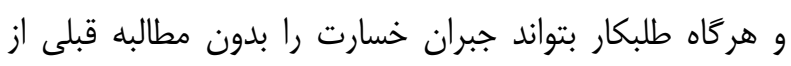
مراجع رسمى درخواست كند. به طريق اولى هركًاه اجراى تعمّد و موعد آن به صورت تعدّد مطلوب باشد، مى دواند درخواست اجراى اصل تعمّد را نيز بخواهد. با اين حال، هر كاه حق تعيين

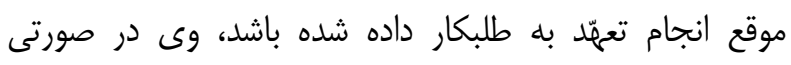

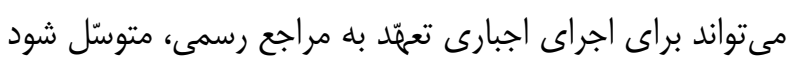

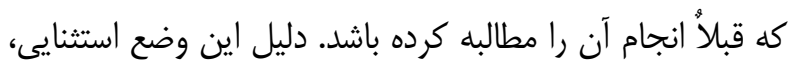

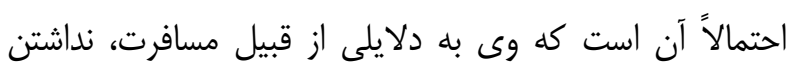

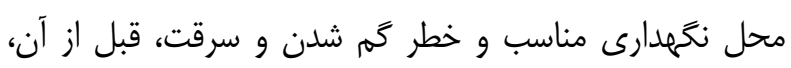
آمادگى يذيرش اجراى تعمّد را نداشته باشد.

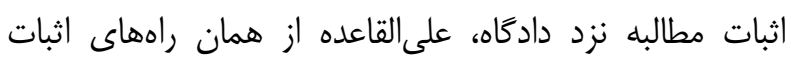
دعاوى مدنى است؛ اما برداشت برخى نويسندكان حقوقى از ماده

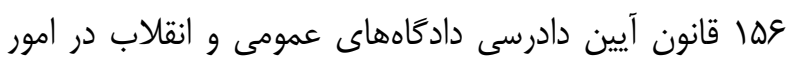

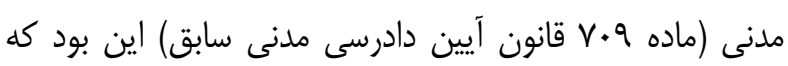

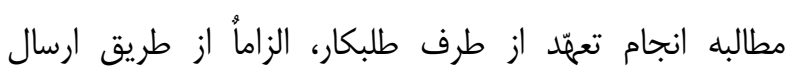

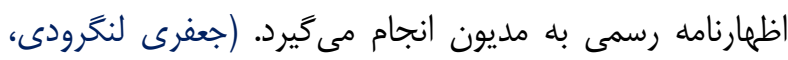
qrY

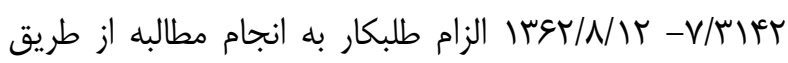
اظهارنامه را به اسناد تجارى نيز تسرّى داده است. (فخارى،

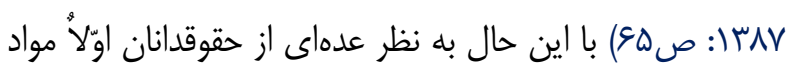

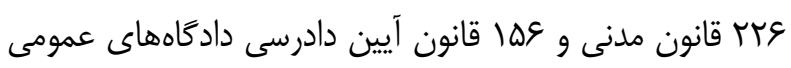
و انقلاب در امور مدنى، اشخاص را مكلّف نكرد تا قبل از تقديم إنها

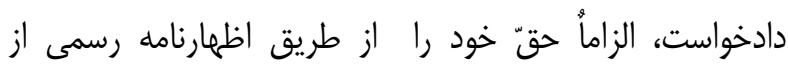

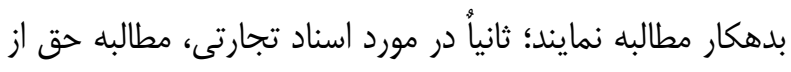

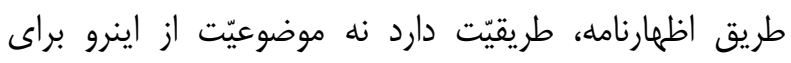

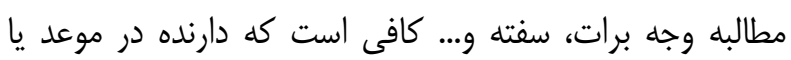


اصلى با رعايت مقرّرات قانونى به هر يك از ظهرنويسها نيز رجوع كند.

ا I-r-r-r تأمين خواسته فراكير: معمولاًا از زمان اقامه دعوا تا زمان صدور حكم و سيس صدور اجرائيه و اجراى آن، مدتّى لمانى نسبتاً طولانى زمان مىبرد تا امكان اجراى حكم دادگاه فراهم آيد. در اين مدت، خوانده مىتواند از طريق جابهابئ مايى اموال

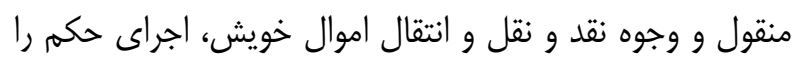
با موانعى روبرو سازد. علاوه براين، طولانى بودن مدت مذكور، ممكن است موجب شود، اموالى كه قبل و در زمان اقامه دعوا

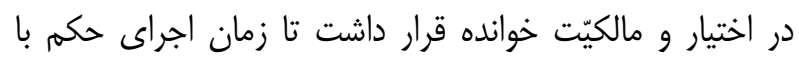

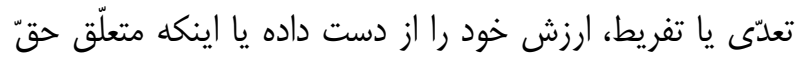
ديخران قرار گيرد. از اينرو، قانونخذار در برابر حفظ حقوق مورد

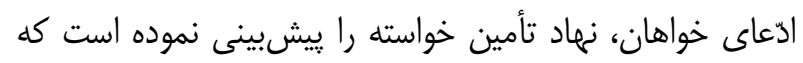
به معناى حفظ كردن و در امنيت قرار دادن خواسته مىباشد.

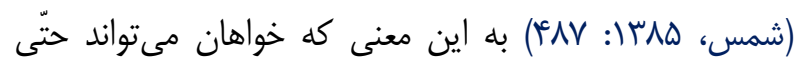

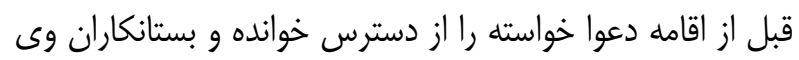

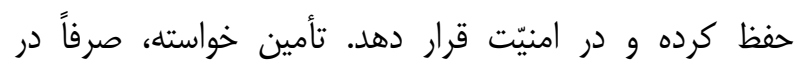
مواردى بكار مىرود كه احتمال صدور حكم به نفع متقاضى زياد

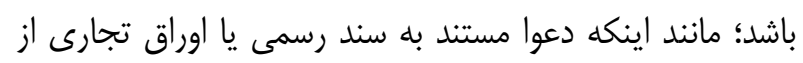

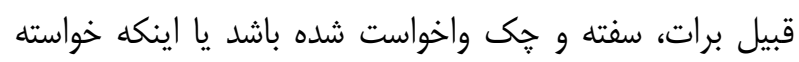
در معرض تضييع و تفريط بوده و عدم اقدام فورى در حفظ آن، اجراى حكم دادكاه را در صورت اثبات حقانيّت متقاضى، دشوار

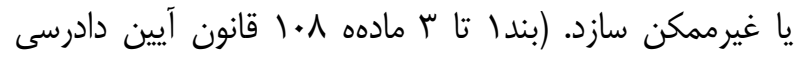

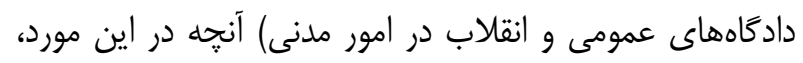

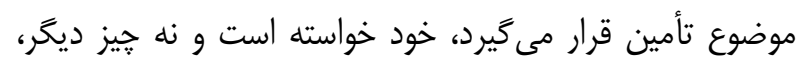

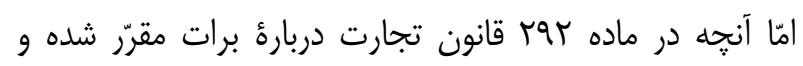
قابل تسرّى به سفته و جیى مىباشد، تمام اموال خوانده اعم از وجوه نقد و ساير اموال منقول و غيرمنقول بلدون توجه به وجود خواسته، معادل وجه مندرج در اسناد مذكور، تحت تأثير حقوق ونا

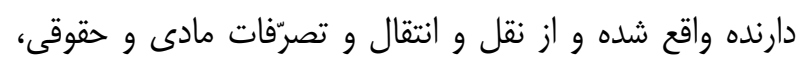
بازذاشته مىشود. تقاضاى خواهان داير بر تأمين خواسته بدون

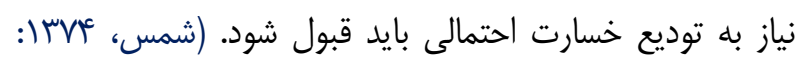

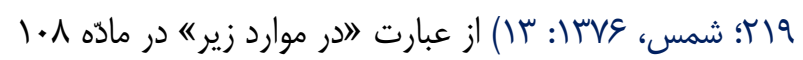

واخواست همين بس كه مطابق ماذه هوب قانون تجارت هيج نوشتهاى نمىتواند جايخزين اعتراض نامه شود، مخر در مورد

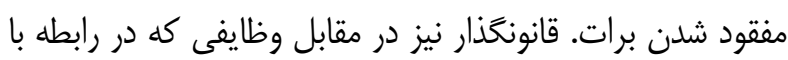
مطالبه يرداخت و انجام تشريفات لازم براى اعتراض بر دارنده تحميل نموده است برخى امتيازات را براى وى در نظر گرفته لهرئه

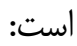
|-r-I- مسؤوليت تضامنى امضاكنندكان: مقبوليّت اسناد تجارتى، ناشى از اعتماد ميان اشخاص در روابط مالى است كه

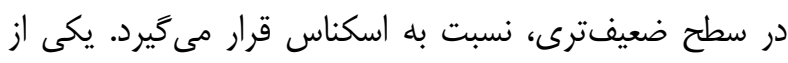
روشهاى جبران اين ضعف، برقرارى مسؤوليت تضامنى ميان اشخاصى است كه تحت يكى از عناوين معاملات براتى (صدور، قبولى، ظهرنويسى و ضمانت، حسب مورد) آنرا امضا مىنمايند.

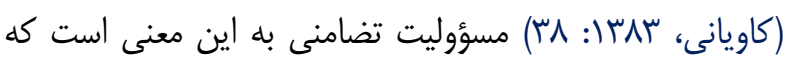
ذمه بدهكار اصلى و ضامن همزمان به يكى دين، مشغول باشد و

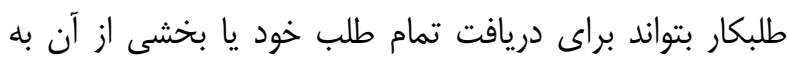
هر كدام از مضمون عنه و ضامن كه بخواهد منفرداً يا مجتمعاً رجوع كند. در ضمان عقدى، اصل بر نقل ذمّه به ذّمه بوده و ضمّ ذّّه به ذّّه يا تضامن، مستلزم تصريح قانونگذار يا قرارداد

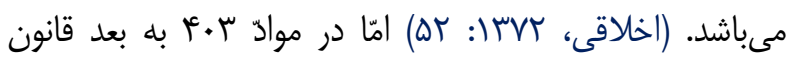
تجارت به قرارداد ضمان تضامنى اشاره شده است.

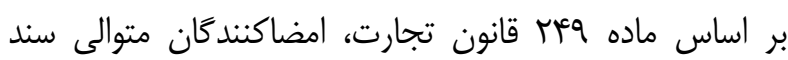
تجارى (براتكش، براتخير، ظهرنويس و... كه به ترتيب وارد

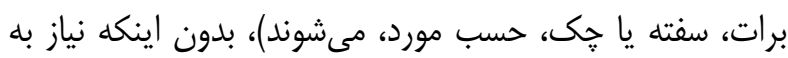

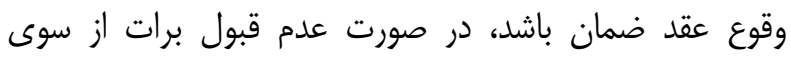

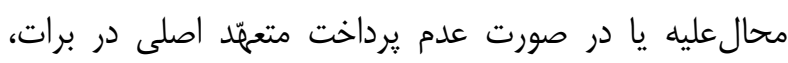

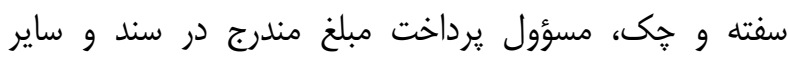
هزينههاى مربوط بوده و دارندة آن مىتواند بدون رعايت ترتيب تاريخى امضاهاى روى سند، تمام مبلغ مورد نظر را از هر يكى از

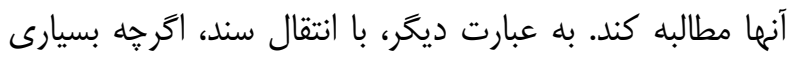

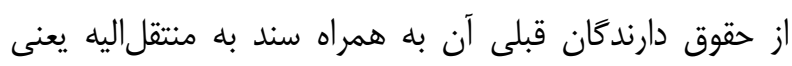

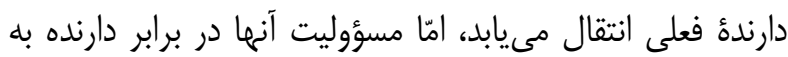
نامبرده منتقل نمى گردد و ذى نفع، حق دارد، علاوه بر متعمّد 
از آنجايى كه هر گاه وجه برات در سررسيد توسّط براتخير يرداخت نشود به اعتبار برات دهنده و ظهرنويسان - كه در برابر دارنده سند، مسؤوليت تضامنى دارند- لطمه وارد مىشود و خطر

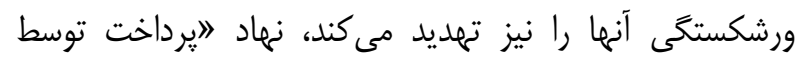
شخص ثالثه ييشينى شده است كه با تأسيس ايفاء دين از

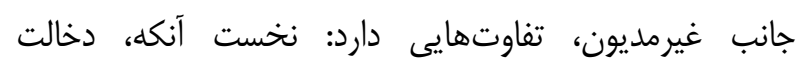

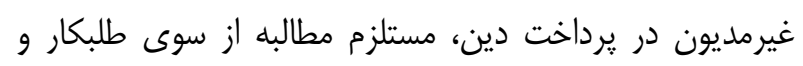

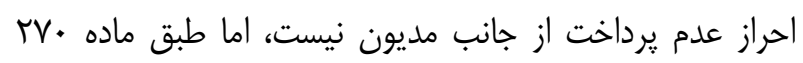

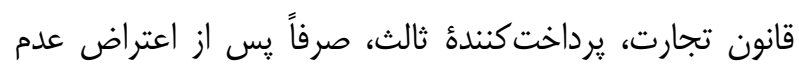

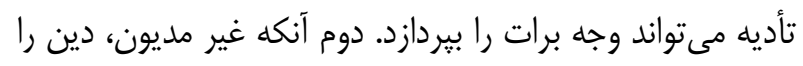
به نفع مديون يرداخت مىنمايد، در حالى كه مداخله ثالث براى

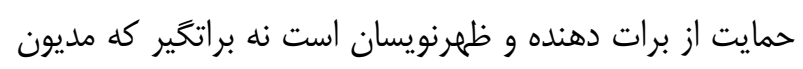
اصلى است. زيرا براتخيرى كه برات را قبول و با وجود اينكه

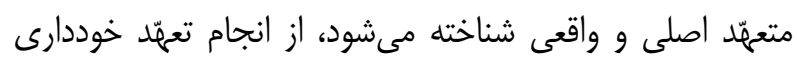
كرده است، قابل احترام نيست تا نهاد مذكور به نفع او ايجاد

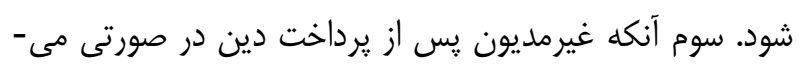

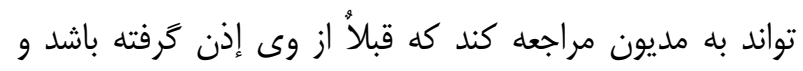

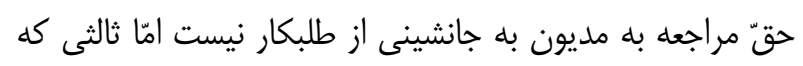

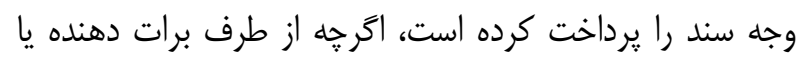

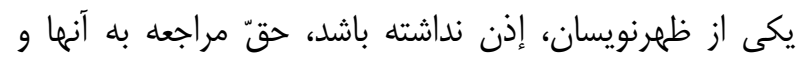

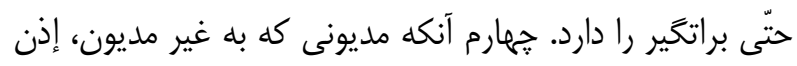

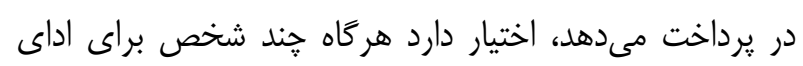

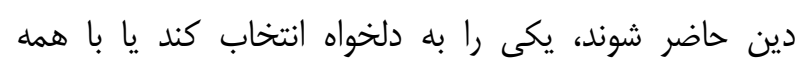
مخالفت نمايد. با اين حال در حقوق اسناد تجارى هركًاه، دارنده با همه مخالفت كند، بدون ترديد نمىتواند وجه برات را از همان

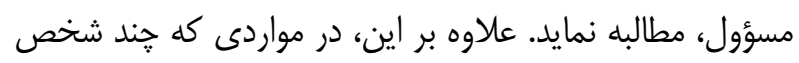
حاضر شوند از طرف جند مسؤول متوالى، دين را يرداخت كنند؛ مناء

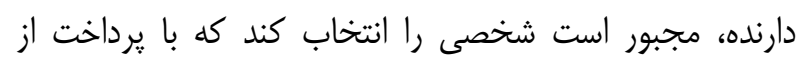
طرف او تعداد بيشترى از مسؤولين، برىالّذّهّه مىشوند. قانون

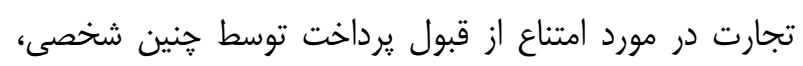
حكم خاصى ندارد، امّا نويسندكان حقوقى به تبعيّت از مقرّرات

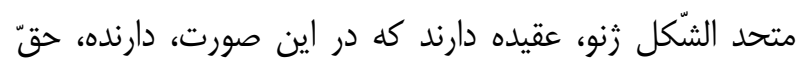

قانون آيين دادرسى دادگاههاى عمومى و انقاب در امور مدنى بر مى آيد كه تحقّق هر يك از بندهاى الف، ب و و ج كافى خواهاى

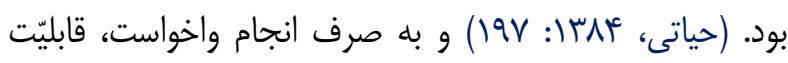

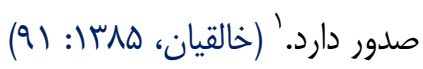
مبناى عدم يذيرش درخواست تأمين خسارت احتمالى در دعواى داى داري

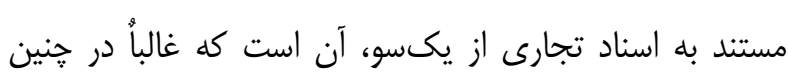

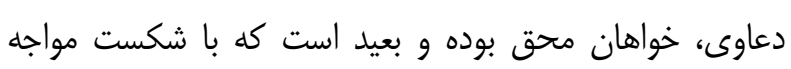
شود. از سوى ديگر، قانونخذار بدين وسيله مى خواهد عموم مردم و مخصوصاُ تجار را به استفاده هرجه بيشتر از اسناد مذكور ترغيب نمايد. (خالقيان، هیrسا: (9) ו-ץ-ץ- امكان برداخت ثالث: مطابق حقوق مدنى، على القاعده، هيج كس بر ديخرى ولايتى ندارد تا در امور او دخالت نمايد؛

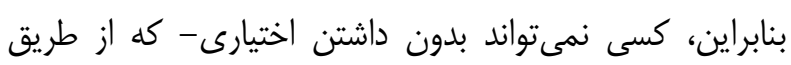

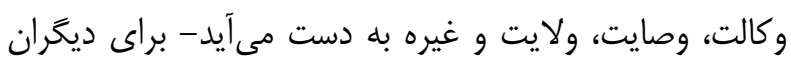

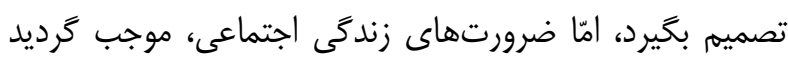

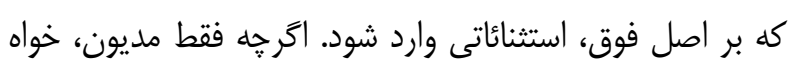
مديون اصلى يا ضامن او، ملزم است دين را بيردازد، با وجود إنى

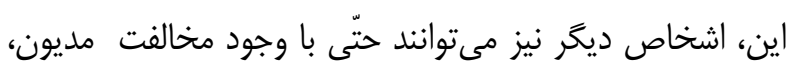

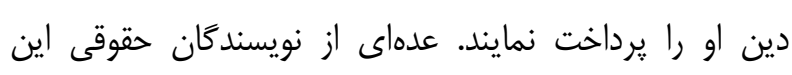

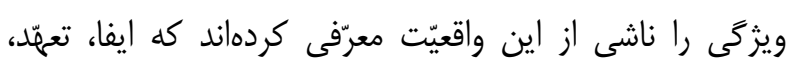
نوعى، واقعه حقوقى است كه اثر حقوقى خود را بر جا مى خذارد.

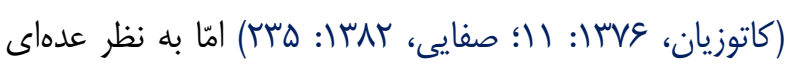

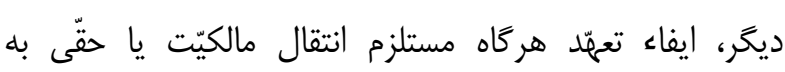

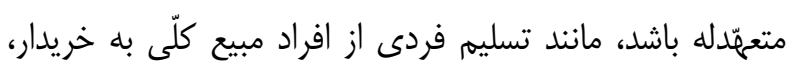
عمل حقوقى محسوب مى شود كه بايد از طرف خود مديون يا

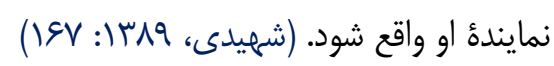

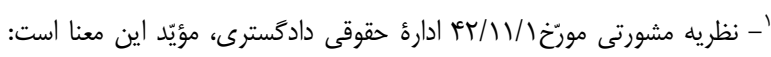

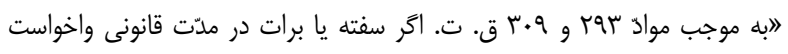

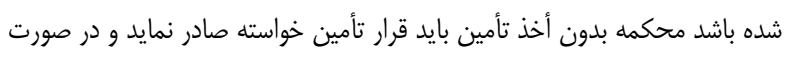

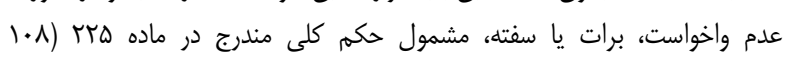

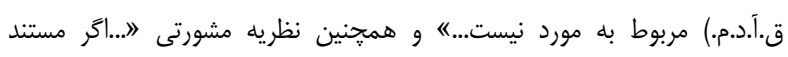

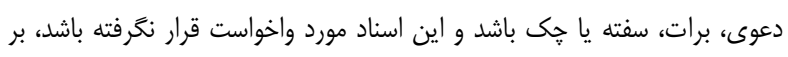

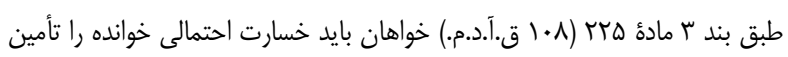

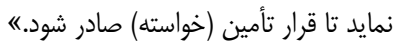


يرداخت اصل دين مىباشند، امّا در برات رجوعى، مسؤوليّت آنها از اصل دين فراتر مىرود. ו-ץ- قبول برداخت جزيى: در حقوق مدنى، تعهل، مجموعه لايتجزائى محسوب مىشود كه بايد به همان صورتى كه ايجاد

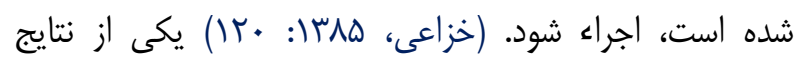

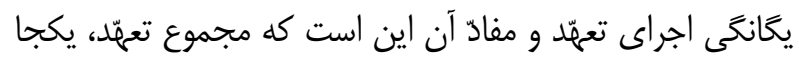

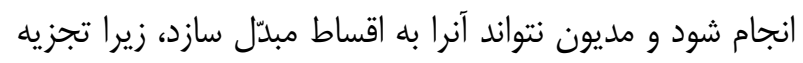

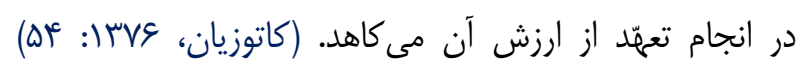

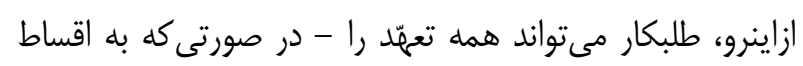

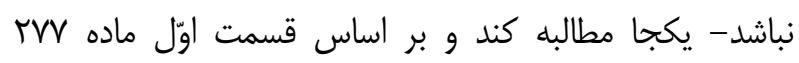
قانون مدنى، متعمّد نمىتواند او را به قبول قسمتى از موضوع

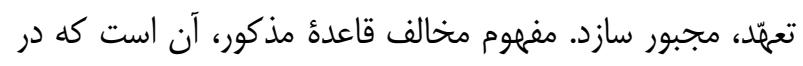

صورتى كه طلبكار به تجزيه دين رضايت دهد، اشكالى ندارد. طبيعت حقوق اسناد تجارى و نيازها و ضرورتهاى ويثة تجار و و

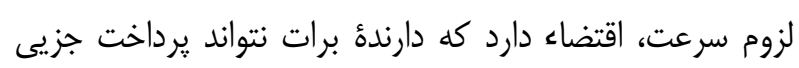

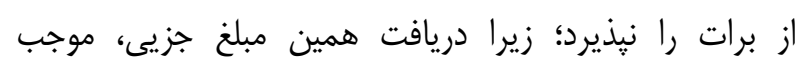
مىشود كه از يك طرف، دارنده، بدهى خود را به تجّار ديخر

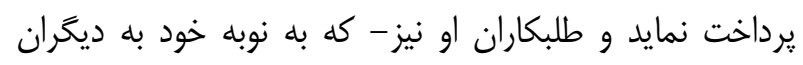
بدهكارند- بدهى خود را به همان مبلغ بيردازند. از طرف ديخر،

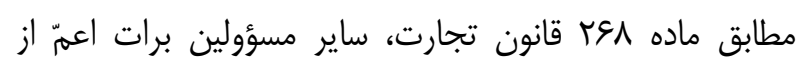

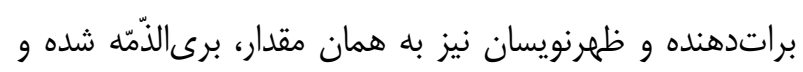
در صورت ورشكستخى براتخير در آينده از بخشى از تعمّدات

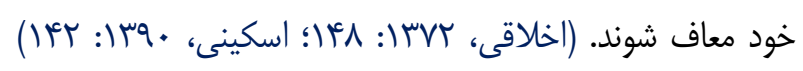
حكم مذكور با ماده وس مقررات متحد الشكل زنو مبنى بر اينكه: ״دارندة برات نمىتواند برداخت بخشى از مبلغ برات را رد كند.... ساز كارى دارد. عدهاى، يِينهاد نمودند كه براتخير براى رفع مسؤوليت از خود، اردا،

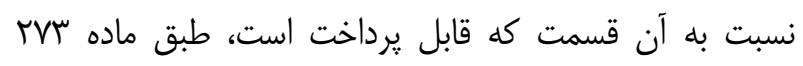

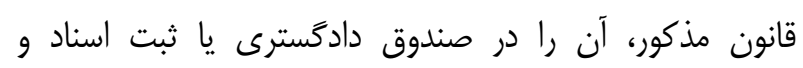

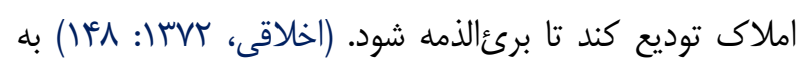

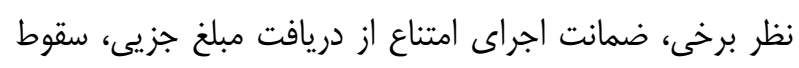

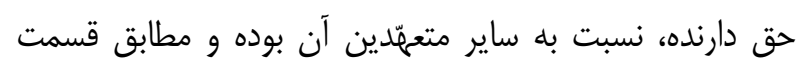
آخر ماده ^عץ قانون تجارت دارنده نيز نمىتواند نسبت بله مبلغ
مراجعه به كسانى را كه يرداخت توسّط ثالث مىتوانست موجب

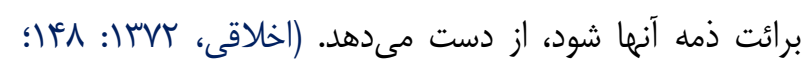

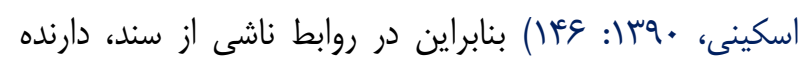
نمىتواند بدون در نظر گرفتن منافع جمعى مسؤولين تضامنى سند، حقوق خود را اعمال كند، بلكه بايد در هر اقدامى، روشى را در ييش گيرد كه نفع تعداد بيشترى را در بر داشته باشد. هركاه

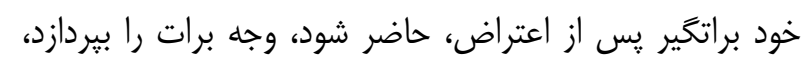
بر هر شخص ديخرى مرجّح است زيرا با اين اقدام، تمام ظهرنويسان و حتى صادركننده و ضامنان هريك از آنها نيز برى درى

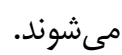
I-Y-Y- امكان صدور برات رجوعى: دارندة براتى كه وجه آن در

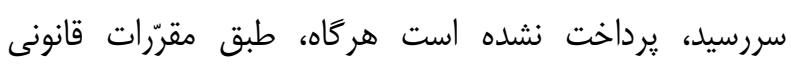

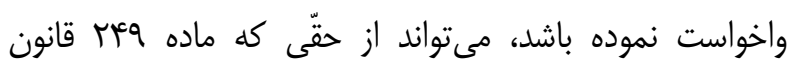
تجارت در اختيار او كذاشته است، استفاده نموده و علئ عليه متعمّدين برات (صادركننده، قبول كننده، ظهرنويس و ضامن، حسب مورد) در مراجع صالح، اقامه دعوى نمايد. دارنده حنين

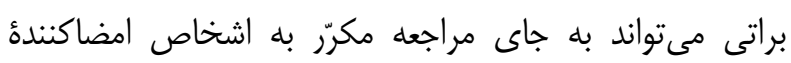

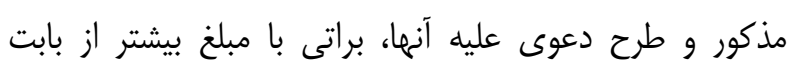
مخارج انجام شده، بر عهده صادركننده يا يكى از ظهرنويسان

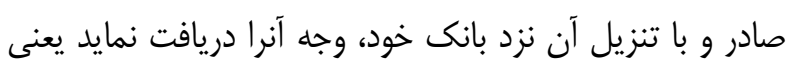
همان كارى را كند كه اشخاص فوق درباره او انجام دادهاند.

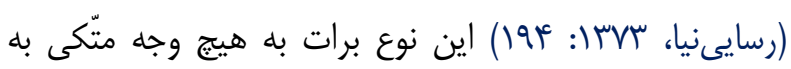
يك رابطه معاملاتى نيست و حتّى قبول برات كه يكى از اركان شكل گيرى و كمال آن محسوب مىشود، مورد توجّه قرار نمى گيرد. اگرجه برات رجوعى، به لحاظ شكلى با برات اصلى تفاوتى

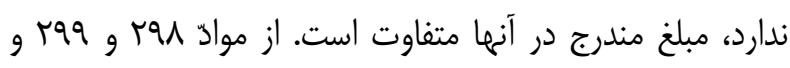

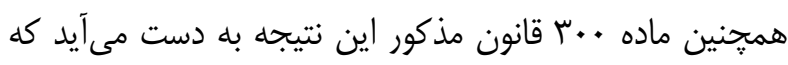
مبلغ برات رجوعى، عبارت است از مبلغ برات اعتراض شده با ماده اضافه مخارج اعتراضنامه و ساير مخارج مانند حقّالعمل رئل

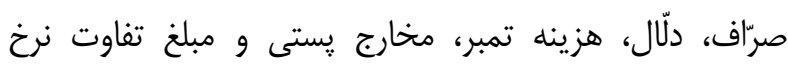

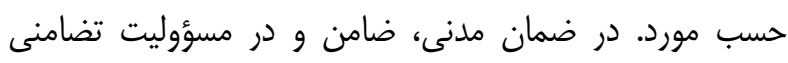

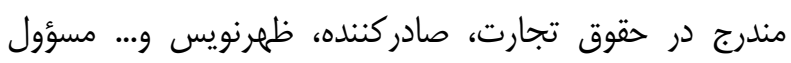


اصلى قرار دارد. به عبارت بهتر، حمايت از يول تجارى و تسهيل

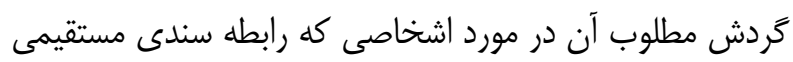
ميان آنها برقرار مىشود در برابر رابطه اصلى، رنى مى مبازد.

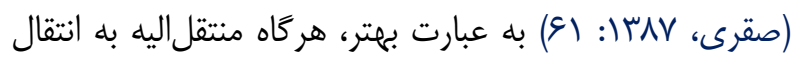

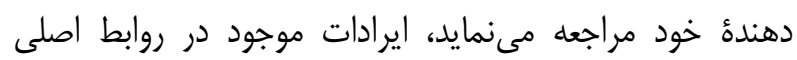

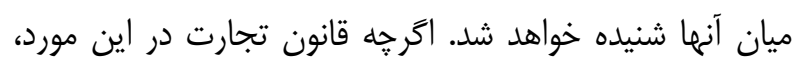
صراحتأ جيزى بيان ننموده است، ولى رويه قضايى در اين مورد

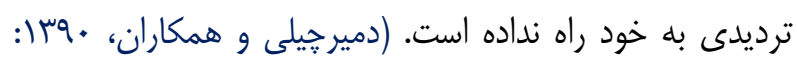

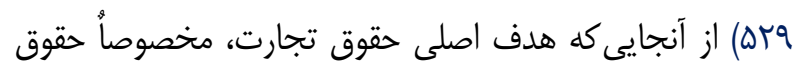

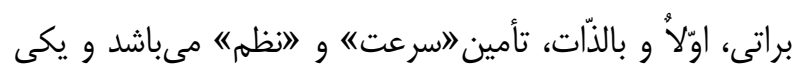

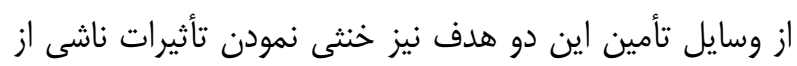

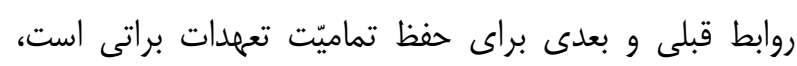

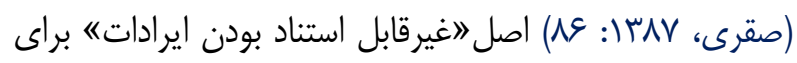
تقويت اسناد تجارتى در برابر اسكناس در روابط براتى (صدور، قبولى، ظهرنويسى و ضمانت)، مطرح شده است. (كاويانى،

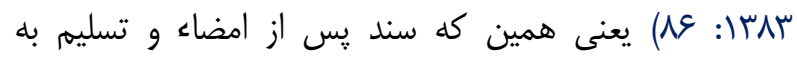
گردش درآمد و از اختيار انتقال گيرنده بلافصل خارج گرديد، ديخر در روابط ميان اطراف غير مستقيم سند، ايرادى شنيده نمىشود؛ زيرا در غير اين صورت، تعداد اين ايرادات به تعداد

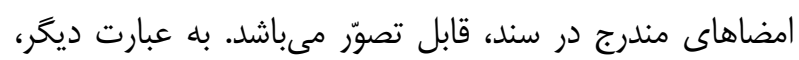
افزايش امضاها بجاى اينكه موجب تقويت اعتبار سند شود،

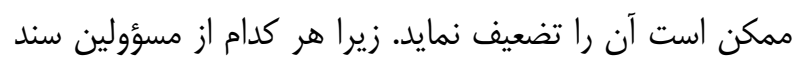

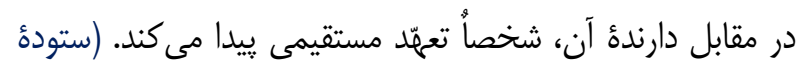

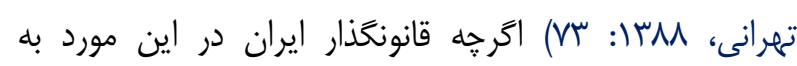
سكوت بركزار نموده است، ولى مفاد آن، همواره مورد احترام

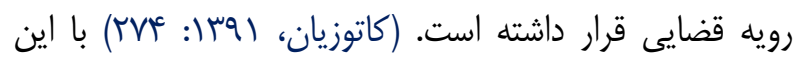

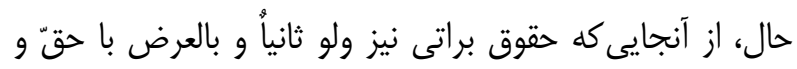

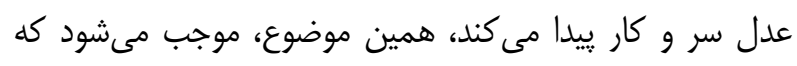

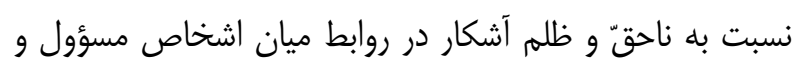
ذينفع در سند- كه فقدان حسن نيّت ناميده مى شود- واكنش

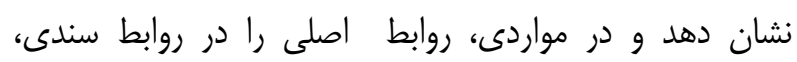
دخالت دهد و به اين ترتيب از مظلوم در برابر ظالم حمايت كند.
قابل يرداخت، اعتراض عدم يرداخت كند. (اسكينى، •وسا:

(I)

1- اقدام از روى حسن نيتّ: مطابق برخى نظامهاى حقوقى

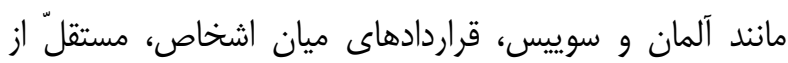

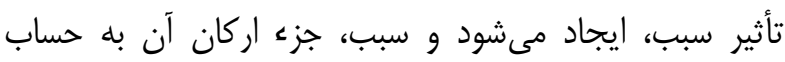

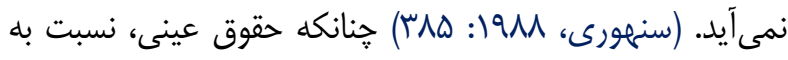

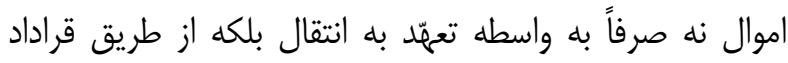

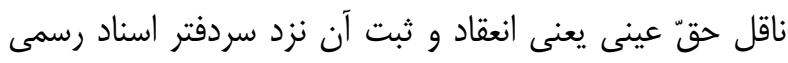

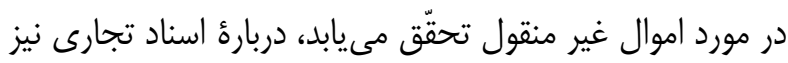

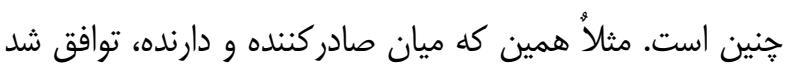

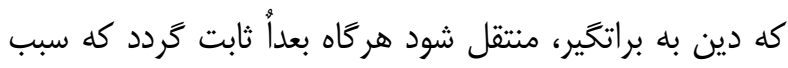

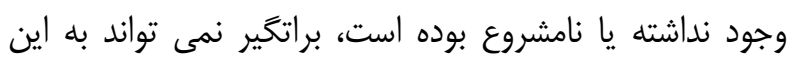

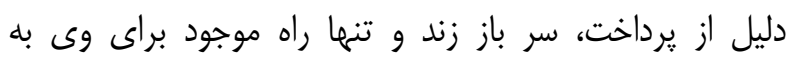

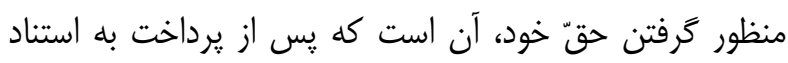

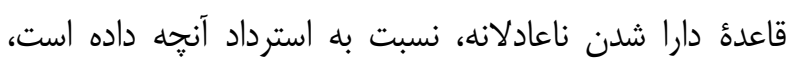
اقدام نمايد. (سنهورى، IMM IN طور كلى، تحت تأثير روابط خارج از سند قرار نمى گيرد.

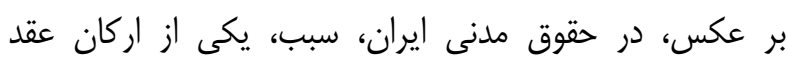

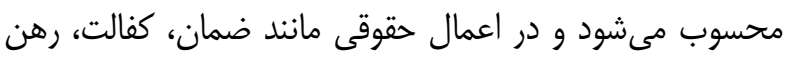
و حواله كه عقودى، تبعى بوده و قبل از آن بايد دينى وجود ماند

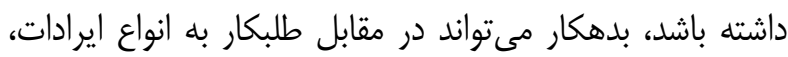

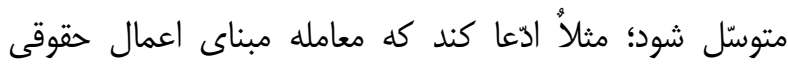

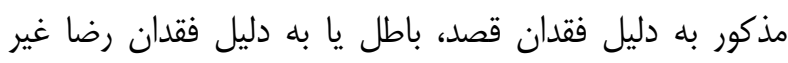

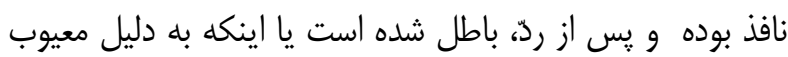

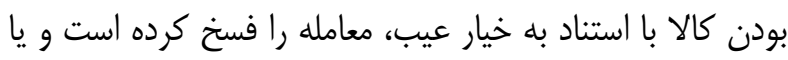
اينكه با قبول بدهى مورد ادّعا، مدّعى تهاتر، تبديل تعمّدّ يا مهاب

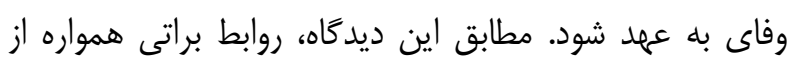
روابط مبنايى، متأثر مى گردد. با اين حال، اكثر نظامهاى حقوق اسناد تجارى، ميان دو ديدكاه فوق راه ميانهاى بركزيدهاند. به اين صورت كه حهن در روابط ميان ايادى بلافصل براتى (براتكش و براتخير، ظهرنويس و انتقال كيرنده، براتكش و اوّلين دارنده) رابطه سندى، تحت تأثير روابط بط بران 
ادّعاها متوسل گردد و از يرداخت وجه امتناع ورزد. جنين ديدكاهى در برخى آراء قضايى متبلور شده است. (كاتوزيان، rrV

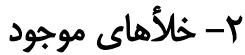

اگرجه قانونگذار، امكان طرح دعوا عليه خوانده و الزام او به ياسخخَويى را در اختيار خواهان قرار داده است، براى خوانده نيز نه تنها فرصت دفاع در برابر دعوا از قبيل استناد به تهاتر را مهيًّا

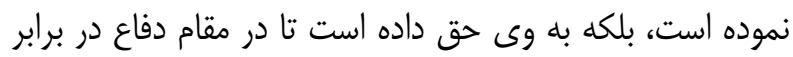
خواهان، ابتكار عمل را در دست گيرد و اقدام به اقامه دعواى متقابل نمايد. با اين حال، در مورد دعاوى مستند به اسناد داد داد تجارى، امكان توسّل به جنين ابزارهاى قانونى از سوى بدهكار، موجب تضعيف موقعيت دارنده را فراهم آورده است: ץ-1- امكان اقامه دعواى تقابل: يكى از طوارى دادرسى مدنى، دعواى تقابل است كه از طرف خوانده دعواى اصلى، عليه خواهان دعواى اصلى اقامه مى شود و با دعواى اصلى ارتباط

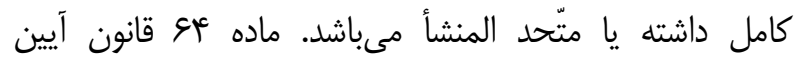
دادرسى مدنى فرانسه در تعريف دعواى تقابل مقرّ مىدارد: "ادعوايى كه به خوانده اصلى اجازه مىدهد براى به دست آوردن منافعى غير از ر3 سادة دعواى طرف مقابل خود اقدام كنده (كريمى، عربا: ع^) در حقوق اسناد تجارى برخى از كشورها به دليل تفكيكى كه ميان رابطه ناشى از سند و رابطه اصلى

r- حكم صادره از شعبه جهارم ديوان عالى كشور، مؤيّد همين معنا است: "...

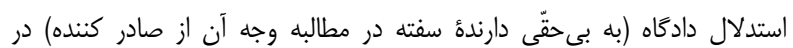

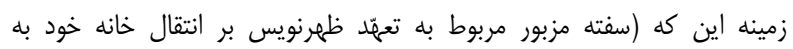

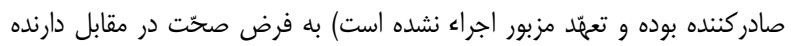

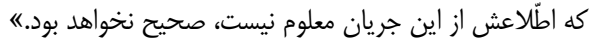

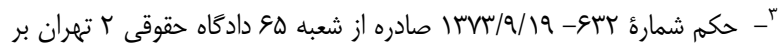

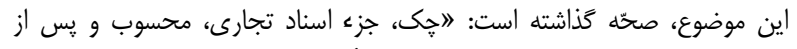

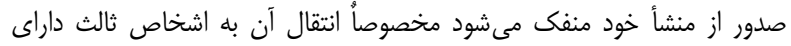

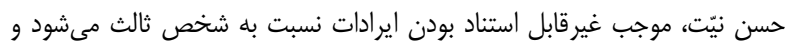

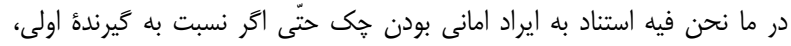

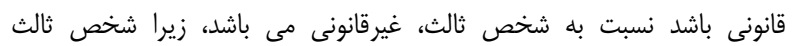

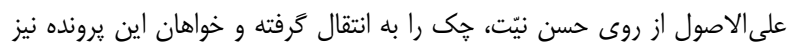

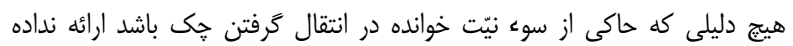

برخى، حسن نيّت را كه از طريق دكترين، وارد ادبيّات حقوقى

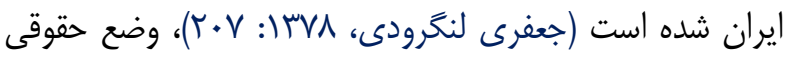
كسى مىدانند كه به تصوّر اينكه كار او قانونى است، از روى اشتباه اقدام به عمل حقوقى مى كند، اين در حالى است كه عمل او در واقع، مطابق قانون نيست، امّا قانونخذار تا حدود معيّى او را مورد حمايت قرار مىدهد، مانند صاحب يدى كه تصوّر

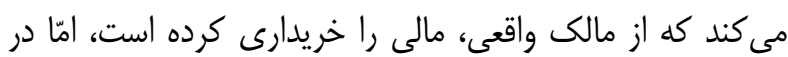

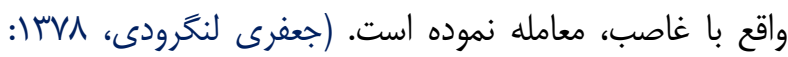

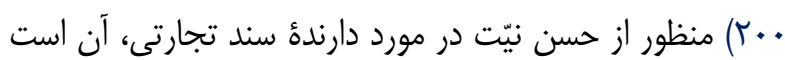
كه وى سند را با اعتماد به وضع ظاهر و با جهل به وجود ايراد

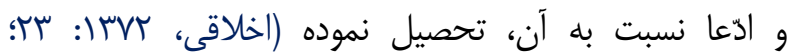

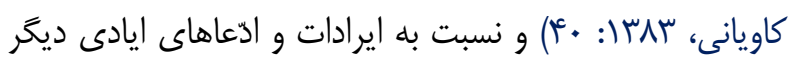

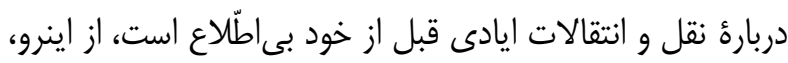

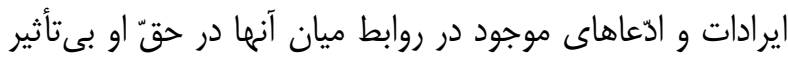
بوده و به عنوان دارنده سند، داراى تمام حقوق ناشى از آن بوده و داراى حقوقى بيش از انتقالدهنده مىباشد. جنين دارندهاى در

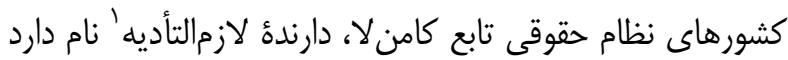
كه نه تنها آن را در برابر ارزش يا عوض در اختيار دارد، بلكه از انقضاى سررسيد يا وجود عيوب و ادّعاها در برابر آن مطّلع نباشد

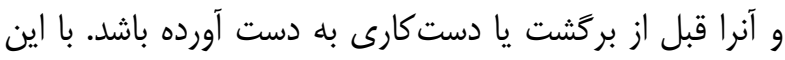
حال، از آنجايى كه اثبات حسن نيّت، دشوار و برخلاف فلسفه

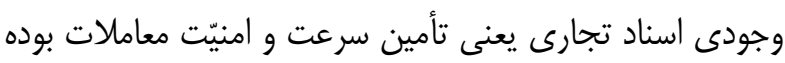

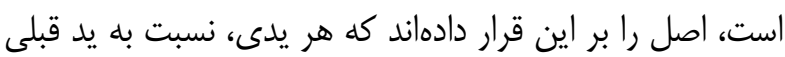
و دارنده فعلى، نسبت به تمام ايادى قبلى، داراى حسن نيّت

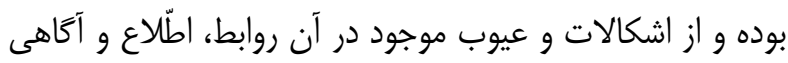
نداشته است؛ مكَر اينكه خلاف آن ثابت شود. از اينرو، هر كاه دارنده- كه سند را از طريق ظهرنويسىهاى متعدّد به دست آورده است- در سررسيد به متعهل رجوع كند يا پِ إز از عدم

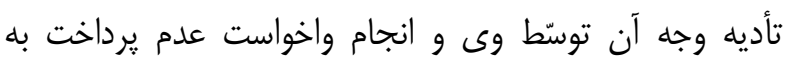
يكى از ظهرنويسان قبلى يا صادركننده مراجعه نمايد، اكرجه ميان آنها رابطه مستقيه براتى وجود نداشته باشد، براتخير، ظهرنويس يا صادركننده مىتواند در برابر او به برخى ايرادات و ولئه

\footnotetext{
1. Holder in Due Course
} 
خود استناد نمايد. (كاتوزيان، اوسا: اسץ؟ جعفرى لنغرودى،

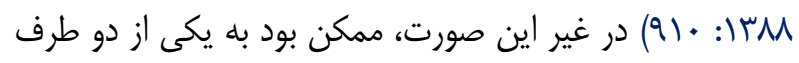

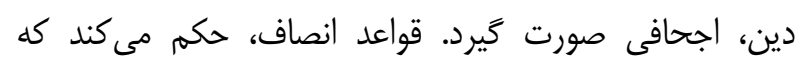
شخصى كه خود به ديخرى مديون باشد، نتواند او را به تأديه

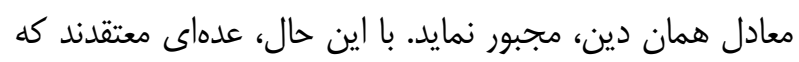
تهاتر، نوعى، وفاى به عهلد و از جمله اعمال حقوقى است.

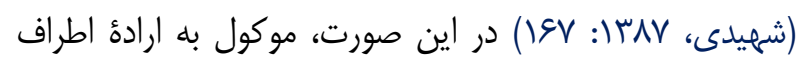

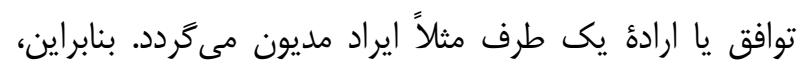

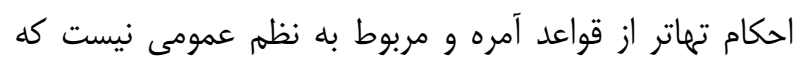
نتوان خلاف آنرا اراده نمود.

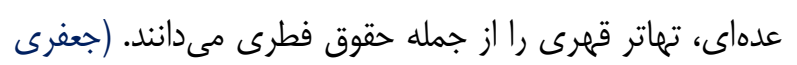

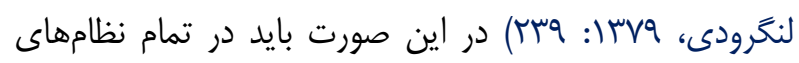
حقوقى، تهاتر قهرى با اجتماع شرايط قانونى، واقع شود با اين حال، برخلاف آنجه در ابتداى امر به نظر ميرسد، جنين امرى

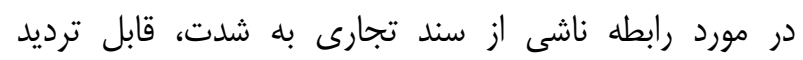

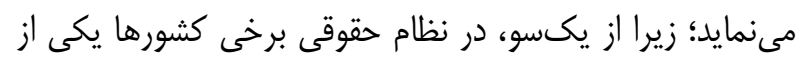

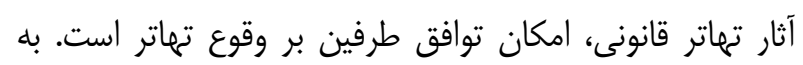

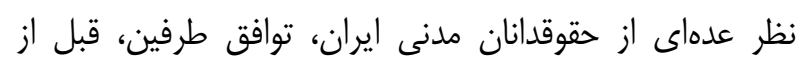

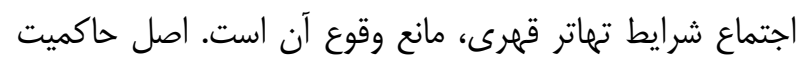

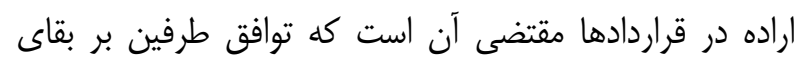
دين در اين مورد معتبر بوده و با قانون مغايرتى نداشته باشد،

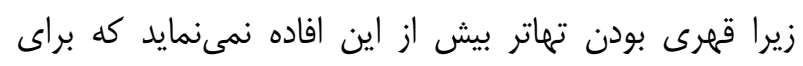

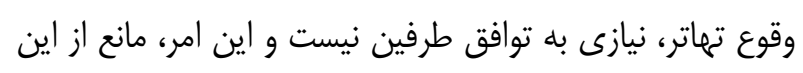
نمىشود كه طرفين با توافق از وقوع تهاتر جلوگيرى نمايند.

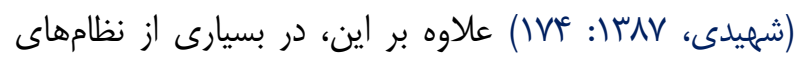
حقوقى اگرجه تهاتر قهرى يذيرفته شده ولى بدون استناد

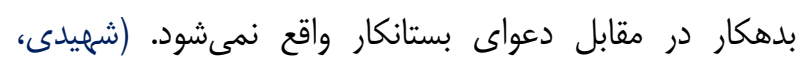

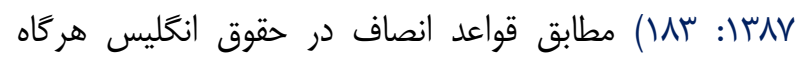
دارنده سند تجارى، آنرا از كسى انتقال گرفته باشد كه خوانده

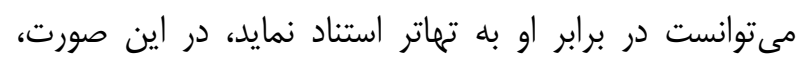

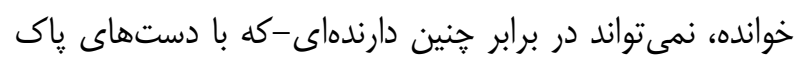

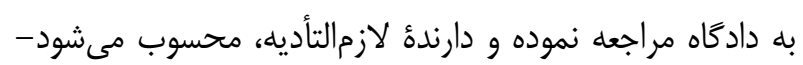

وجود دارد، امكان طرح دعوى تقابل از سوى خوانده در مقابل

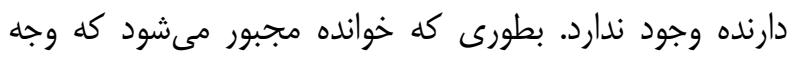
سند تجارى را به طور كامل بيردازد و در صورت تمايل، دعواى مستقلّى درباره رابطه خارج از سند مثلاً كيفيّت كالاهاى

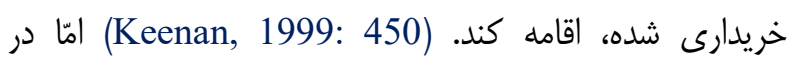
حقوق ايران، اكرجه هيج متن قانونى در مورد عدم امكان طرح

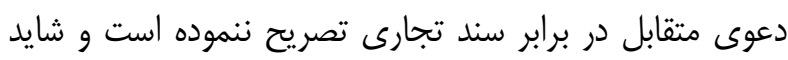
به همين دليل نيز برخى قايل به امكان دعوى تقابل در برابر

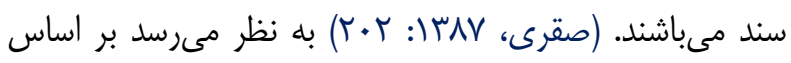
ماده•rץ قانون تجارت در صورت انجام تشريفات واخواست، امكان طرح دعوى تقابل در برابر دعواى دارنده با واسطه سند، لهار منتفى باشد. ץ-Y- امكان استناد به تهاتر: در فقه، تهاتر، امرى، قهرى است.

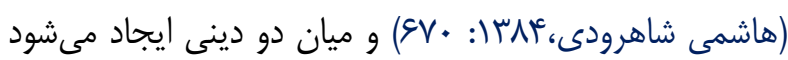

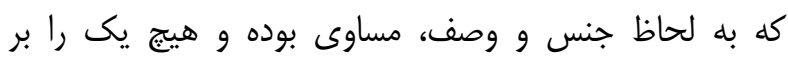

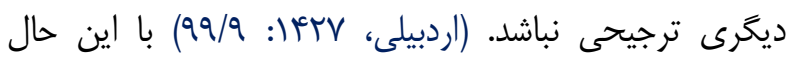
دربارهٔ مفهوم تهاتر قهرى، اتفاق نظرى وجود ندارد بند هـ ماده

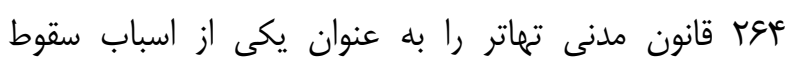

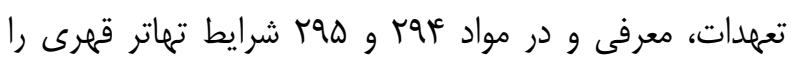
مقرر نمود بدون اينكه تعريفى از آن ارائه نمايد. در فقدان تعريف

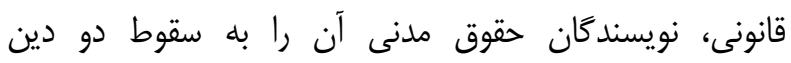
همجنس كه به طور متقابل بين دو شخص وجود دارد (عدل، مدان

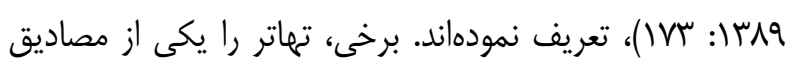
وفاى به عهد و در زمره وقايع حقوقى به حساب مى آورند.

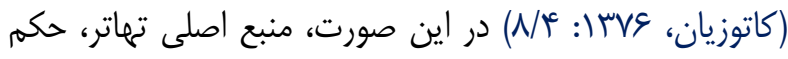

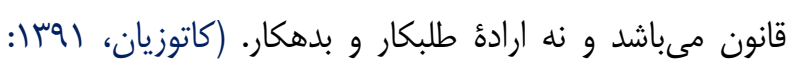
هأ) از اين رو، تهاتر، وسيلهاى براى ساده كردن دو يرداخت

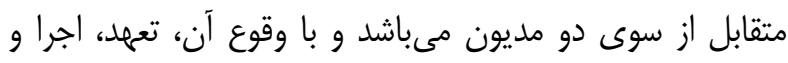

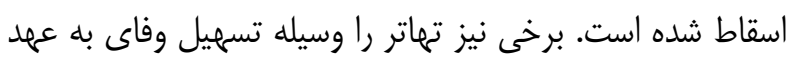

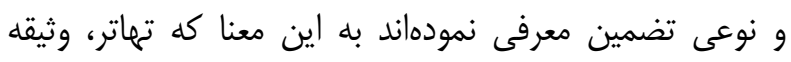

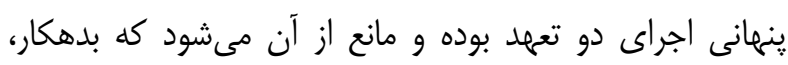
طلبى را كه از ديخرى دارد، بخيرد و در مقابل مطالبه او به اعسار 
خود بعد از تاريخ مزبور معين كرده خودبخود و بطور قهرى،

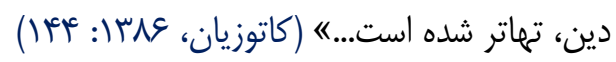
با سكوت قانونَّار و تشتت در آراء قضايى، دكترين حقوقى نيز

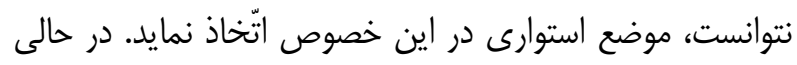

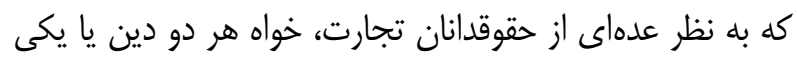
از آندو، مستند به سند تجارتى باشد در رابطه ميان دارنده سند و

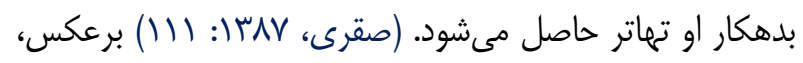
گروهى ديخر، بدون تفكيك ميان دو وضعيت فوق، عقيده دارند كه ميان دارندة سند و بدهكار او تهاتر واقع نخواهد شد، زيرا دارنده براى آنكه با تهاتر روبرو نشود به اخذ سند، رضايت داده

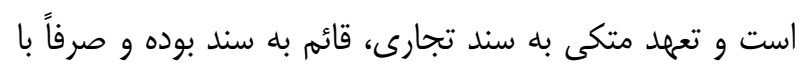
يرداخت يا تحويل اختيارى آن به بدهكار، زايل مىشود. (كاتوزيان، r-r-تأثيريذيرى از محل: محل، عبارت است از طلب برات برات

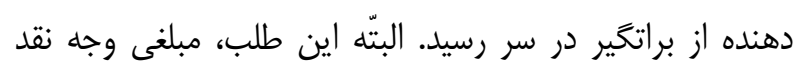

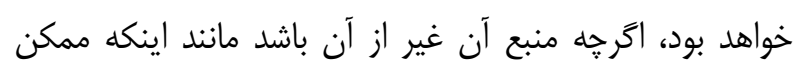

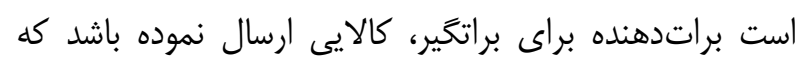

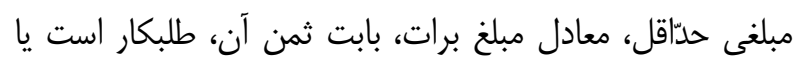

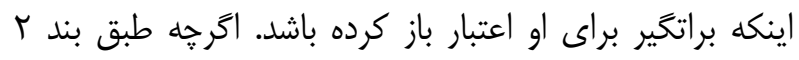

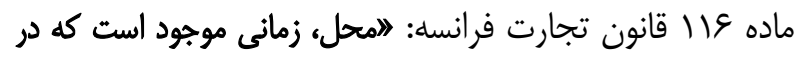
سررسيد برات، براتكير حد اقل معادل مبلغ برات به صادركننده

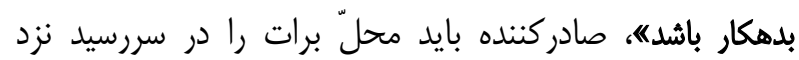

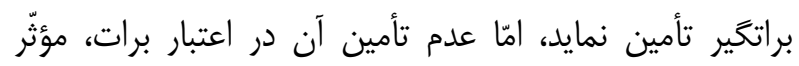

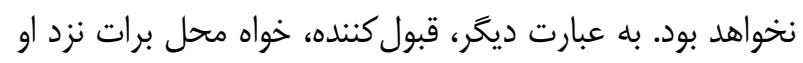

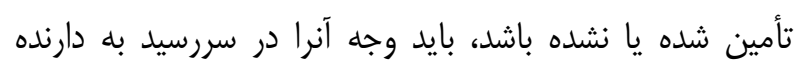

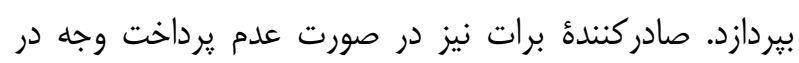
سررسيد و اعتراض، مسؤول تأديه وجه برات خواهد بود خواه

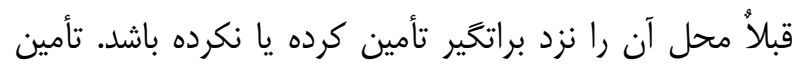

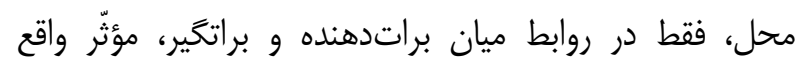

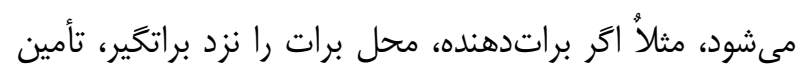

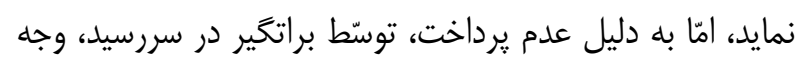

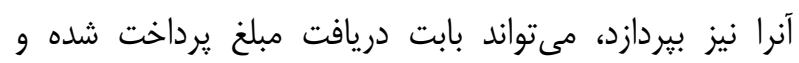

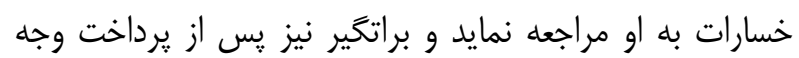

به تهاتر مبلغ مندرج در سند با طلب خود از انتقالدهنده آن، استناد كند. دارنده لازمالتأديه در حقوق كشورهاى تابع نظام حقوقى كامنلا، نه تنها سند تجارى را قبل از برگشت يا دستكارى آن در برابر ارزش يا عوض در اختيار كرفته است،

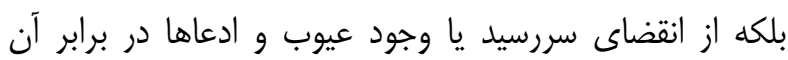
مطلع نبوده است. هنين دارندهاى، داراى حسن نيت فرض مر مئ-

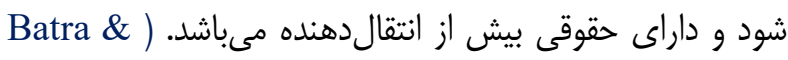
(Kalra, 1988: 308; Mann \& Roberts, 2007: 473 حسن نيت، اگرجه از طريق دكترين، وارد ادبيات حقوقى ايران شده است، در حقوق اسناد تجارى ايران، تحت عنوان اصل العدم يذيرش ايرادات در برابر دارنده با حسن نيتها، مورد

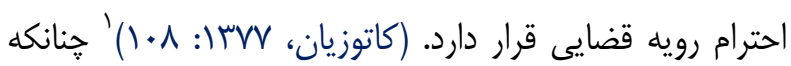

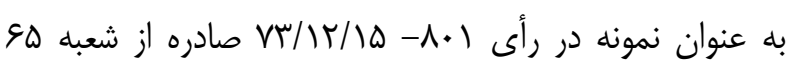
دادكاه حقوقى دو تهران در اين خصوص آمده است: الدارنده جى موضوع دادخواست اصلى غير از آقاى.... است. نتيجتاً رابطه ميان خواهان و خوانده، رابطه ناشى از اسناد تجارى و أنى برواتى است و بنابراين در جنين رابطهاى اسناد تجارى، مصون از ايراد بوده و نسبت به اشخاص ثالث با حسن نيّت نمى توان

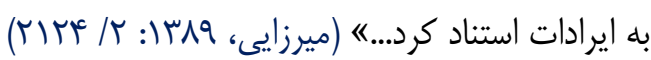
با اينكه در قوانين مربوط به اسناد تجارى ايران به امكان استناد به تهاتر، اشارهاى نشده است، برخى آراء قضايى به امكان تهاتر

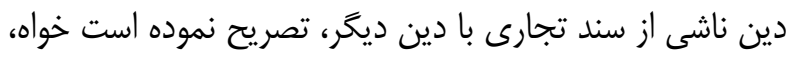

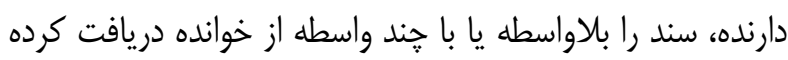

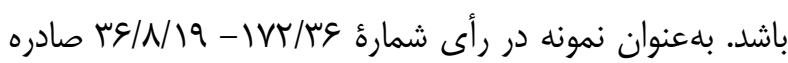

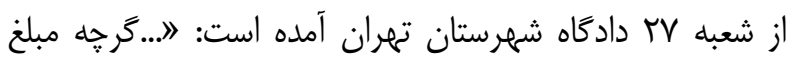
اجناس فروخته شده در صورتحساب مورد استناد به سياق نوشته شد... برخى اقلام آن... به تنهايى براى استيعاب طلب مُحساب مورد

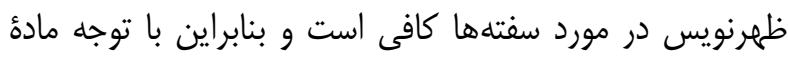
هوץ قانون مدنى و اينكه واخوانده نيز تاريخ انتقال سفتهها را به

' - ا... استدلال دادكاه (به بع حقى دارنده سفته در مطالبه وجه آن از صادركننده) در زمينه اينكه (سفته مزبور مربوط به تعهد ظهرنويس بر انتقال خانه خود به داه صادركننده بوده و تعهل مزبور اجراء نشده است) به فرض صحت در مر مقابل دارنده كه اطلاعش از اين جريان معلوم نيست، صحيح نخواهد بود. 
است. مطابق ماده الج همان قانون اگر خه يس از صدور و

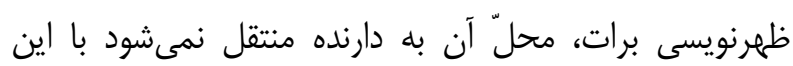

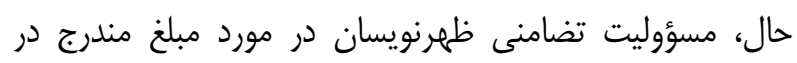

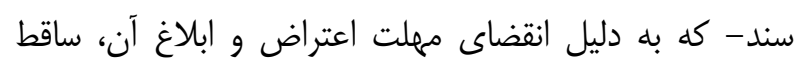

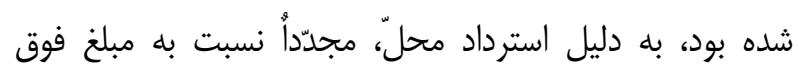

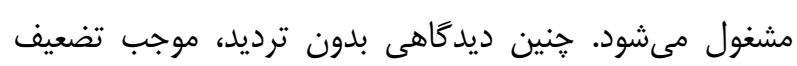
رابطه ناشى از سند خواهد بود.

\section{r- حقوق بلدون تكليف}

قانونخار در برخى موارد بدون اينكه تكليفى در راستاى تسهيل يرداخت وجه مندرج در سند بر دارنده تحميل نموده باشد، اقدام

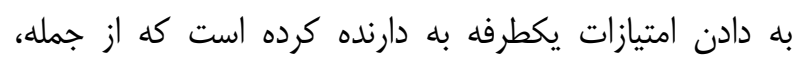
امكان درخواست تأمين دعواى واهى و تأمين اتباع بيحانه بدون واخواست، امكان دخل و تصرف دارنده در سند به زيان مسؤولين تضامنى و مطالبه مبلغ غير مندرج در سند است. ץ-1- عدم يذيرش درخواست تأمين دعواى واهى: براساس

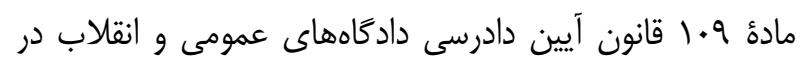
امور مدنى به خوانده دعوى حق داده شد كه در برخى موارد از

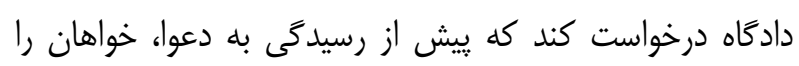

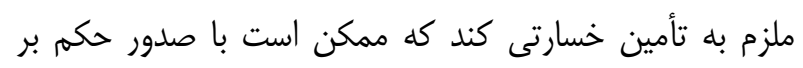
بى حقّى او در دعوا بابت هزينه دادرسى و حقّ الوكاله وكيل

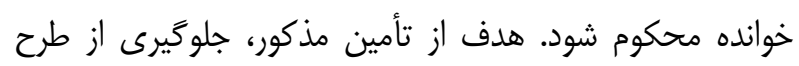
دعاوى بى يايه و تضمين جبران خسارات ناشى آن است. منظور

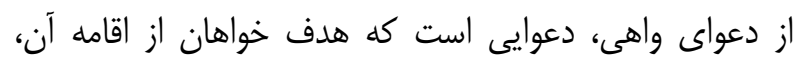

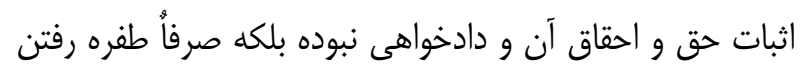

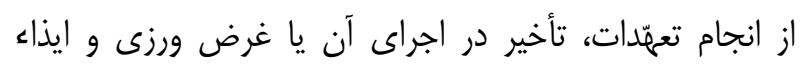
خوانده از طريق سوء استفاده از مراجع قضايى است. (خالقيان،

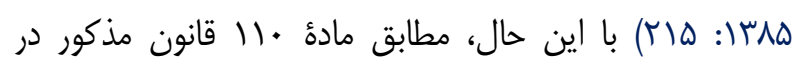

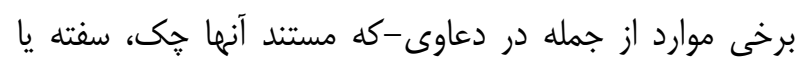
برات باشد، خواندة دعوى از درخواست تأمين دعواى واهى

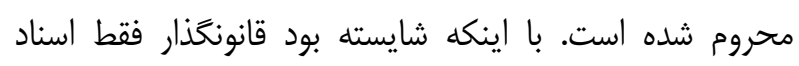
تجارى واخواست شده را مشمول خنين امتيازى قرار مىداد، ظاهراً در اين خصوص ميان اسناد تجارى واخواست شده و
آن در صورت عدم تأمين محلّ مىتواند آن، مبلغ را از

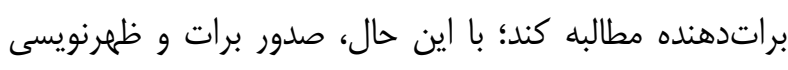
بعدى آن، موجب انتقال محلّ آن به دارنده مى كَردد (اسكينى،

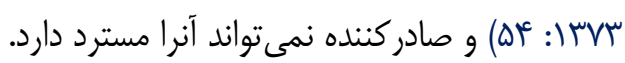
عدهاى از نويسندكان حقوقى عقيده دارند در حقوق انگليس نيز

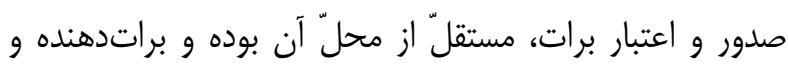
براتخير صرفاُ به دليل امضا و تسليم برات، متعمّد يا مسؤول

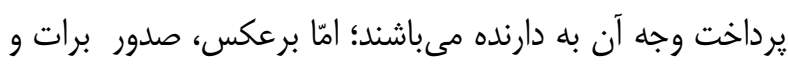
ظهرنويسى بعدى آن، موجب انتقال محلّ به دارنده نمى گرَدد.

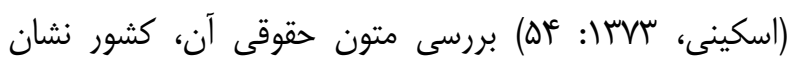
مىدهد كه "عوض" يكى از مفاهيم بنيادى حقوق قراردادهاى منى

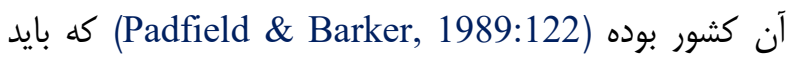
ناشى از همان معامله باشد. تنها تفاوتى كه وجود دارد اين است كه در حقوق اسناد تجارى، عوض مىتواند كذشته يعنى ناشى از

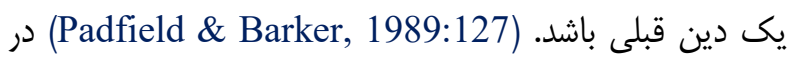
حقوق ايران نيز تأمين محل، شرط صدور و اعتبار برات نيست،

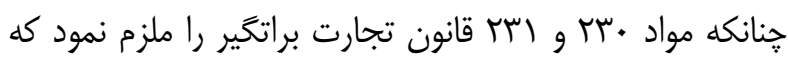

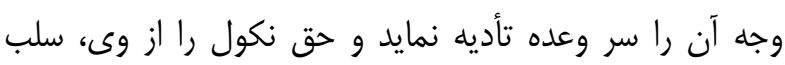

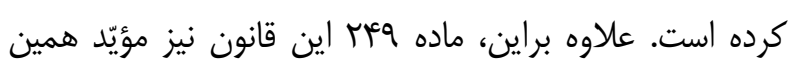

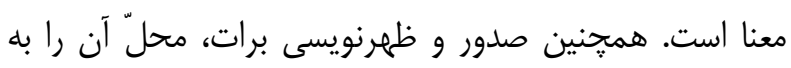

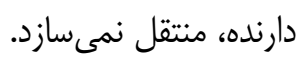
علىرغم قطع ارتباط تعمّدات ناشى از رابطه سندى با محلّ در

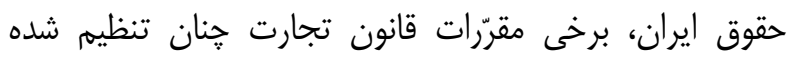

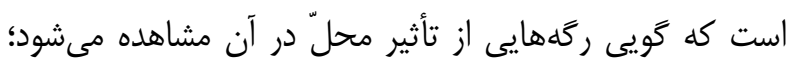

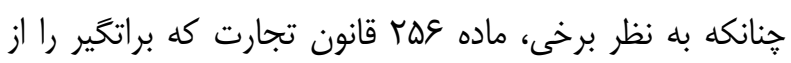

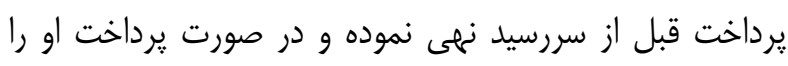

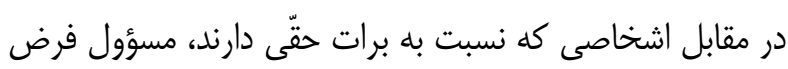

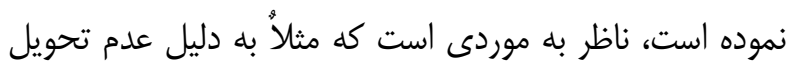

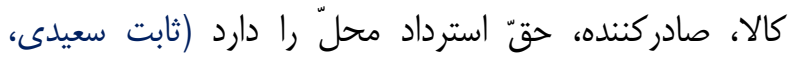

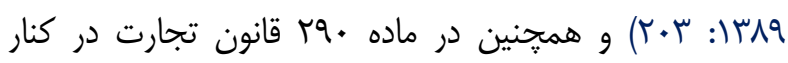

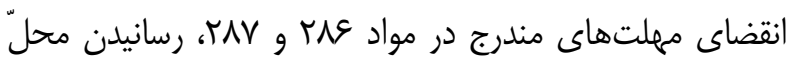

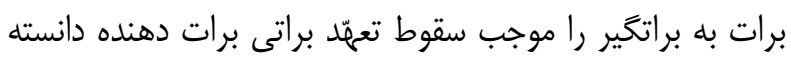


خارجى، عليه خواندهُ تبعه ايرانى يذيرفته شده است، با اين حال،

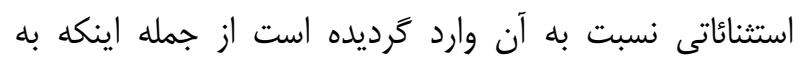

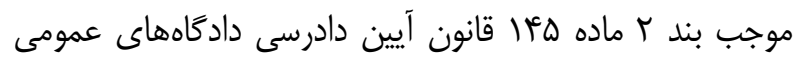
و انقاب در امور مدنى، هركاه دعواى خواهان تبعه بيخانه، عليه خوانده ايرانى، مستند به اسناد تجارى از قبيل جیى، سفته يا برات باشد، وى از دادن جنين تأمينى معاف شده است. ظاهراً مبناى عدم يذيرش درخواست تأمين از اتباع بيخانه در اين مورد، حفظ و تقويت اعتبار اسناد مذكور در تجارت بينالملل و وجود احتمال قوى در محق بودن خواهان مىباشد و قانونخذار بدون

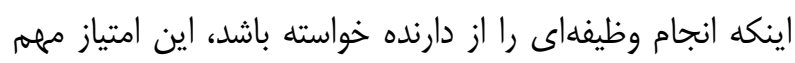

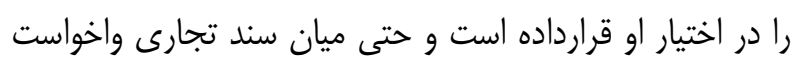

شده و واخواست نشده، تفاوتى قائل نشده است. ץ-ץ- امكان مطالبه يول خارج از برات: برات، علاوه بر معاملات داخلى در تجارت بينالمللى نيز به عنوان وسيله

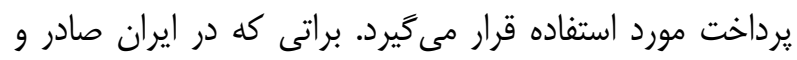
به گردش در مىآيد، على الاصول، متضمن دستور يرداخت مبلغ معينى وجه رايج كشور مىباشد. مطابق بند ج ماده r قانون يولى و بانكى كشور، تعهد يرداخت هرگّونه دين يا بدهى مخر اينكه با رعايت مقررات ارزى كشور، ترتيب ديخرى بين بدهكار

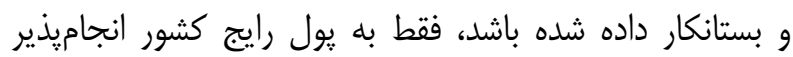
است. در خريد و فروشهاى بينالمللى از طريق اعتبارات

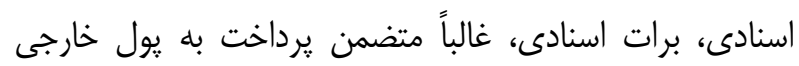
است، از اينرو، ماده rar قانون تجارت مقرر نمود: لايرداخت برات با نوع يولى كه در آن معين شده به عمل مىآيد.ه با اين حال،

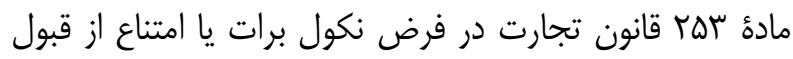

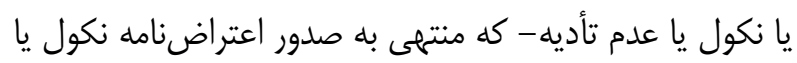
عدم يرداخت گَردد- در مورد نوع يول قابل مطالبه از براتخير در مقايسه با ساير متعهدين سند از جمله براتدهنده و ظهرنويسان، قايل به تبعيض شده است. اگرجه از براتخير فقط همان يولى را مىتوان مطالبه كرد كه در برات تعيين شده است، اما دارنده،

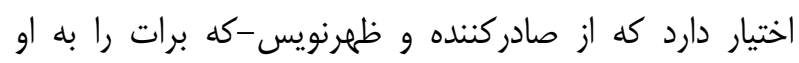
منتقل كرده است- يول مندرج در برات يا نوع يولى را كه به او او داده است، مطالبه كند. پذيرش اختيار دارنده به مطالبه مبلغ
واخواست نشده، تفاوتى وجود ندارد. (خالقيان، همبا: 19 آ؛

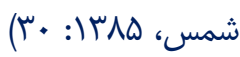

r-r-r عدم ثذيرش درخواست تأمين تأمين اتباع بيكانه: حق

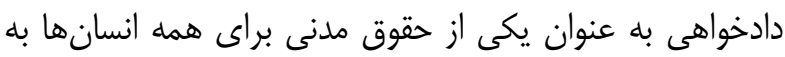
رسميّت شناخته شده است. مطابق مواد ل و 1 اعلاميه جهانى لئى

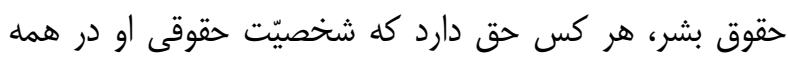

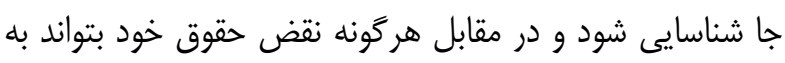

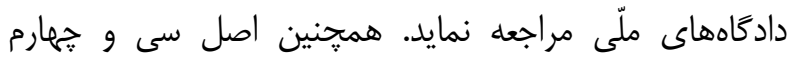
قانون اساسى جمهورى اسلامى ايران، دادخواهى را حقّ مسلّم

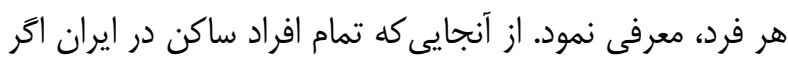

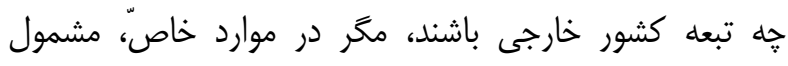

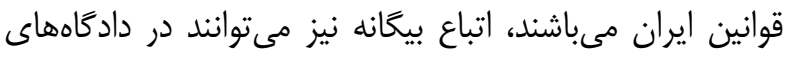

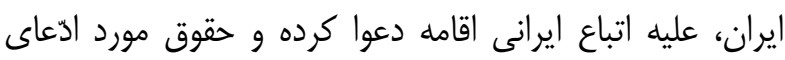

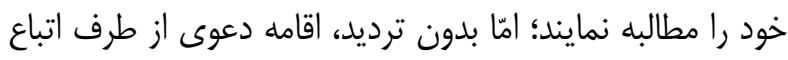
خارجى، عليه اتباع ايرانى در برخى موارد، مخاطراتى براى خواندة ايرانى در بر دارد و او را در موقعيّت ضعيف ترى قرار مىدهد، زيرا هركاه خواهان تبعه خارجى - كه در ايران اموالى درد

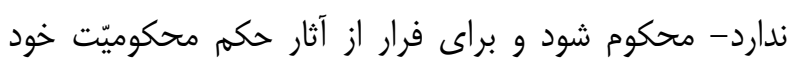

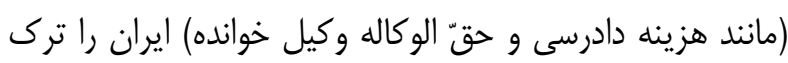
نمايد، خوانده ايرانى كه حكم برائت او صادر شده است اگر بخواهد خسارت دادرسى را از خواهان -كه محكوم به بـى حقّى شده است- مطالبه نمايد، دستش به جايى بند نبوده و خارهاى جز تحمّل ضرر نخواهد داشت؛ زيرا حتّى در صورت كرفتن حكم

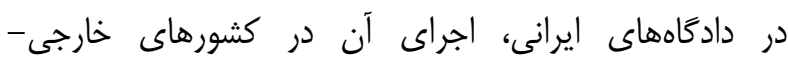

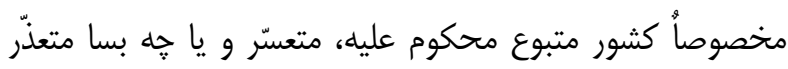
باشد، از اينرو، براى رعايت اصل تساوى طرفين دعوا در مقابل

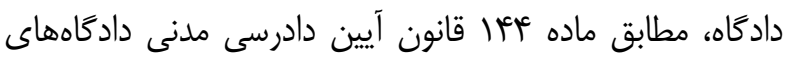

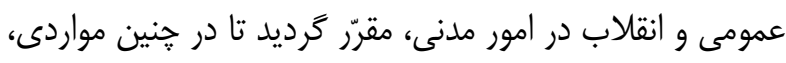

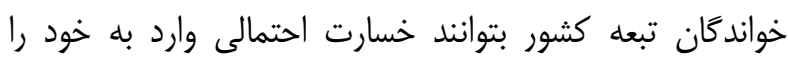

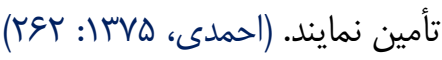
در حال حاضر در اكثر نظام هاى حقوقى، استفاده از نهاد مذكور،

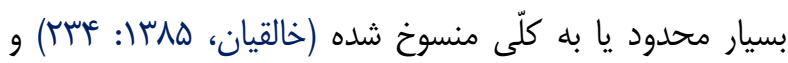
در حقوق ايران نيز اگرجه به عنوان يك اصل در دعواى تبعه 
اينكه در برخى موارد، مبلغ مندرج در سند به وجود و انتقال

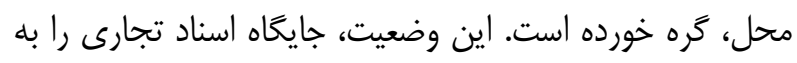

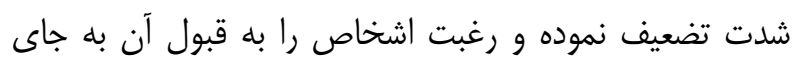
وجه نقد، كاهش داده است. ج. بهم خوردن تعادل ميان امتيازات و تكاليف دارندهُ سند تجارى به تضييع حقوق او منحصر نمى شود بلكه دادن امتيازات

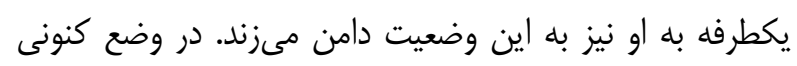
در برابر دعواى دارندة سند تجارى به صرف اطلاق اين عنوان بر او و بدون اينكه نياز به واخواست عدم قبولى، عدم يرداخت و اخذ گواهى عدم يرداخت،حسب مورد، باشد، خوانده نمىتواند

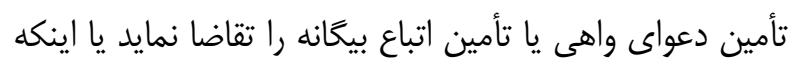
او مىتواند موعد يرداخت را كم يا زياد كند، با انجام اقدام

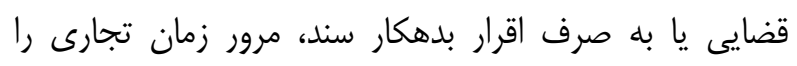

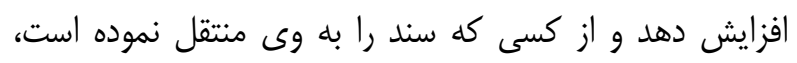
نوع يولى را به وى داده است يا يولى كه در سند منعكس شده رها است، مطالبه نمايد. ملاحظات اخلاقى: موارد مربوط به اخلاق در يزوهش و نيز

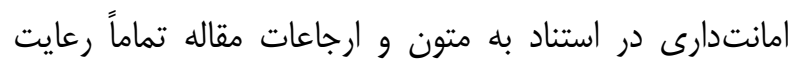
كرديد.

تعارض منافع: تدوين اين مقاله، فاقد هرگونه تعارض منافعى

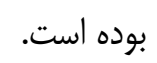

سهم نويسندكان: نغارش متون و انجام اصلاحات نهايى

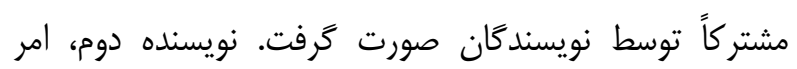
نظارت علمى را نيز عهدهدار بوده است.

تشكر و قدردانى: از تمامى كسانى كه در تهيه اين مقاله ما را يارى رساندند، تشكر مىنماييم.

تأمين اعتبار يُوهش: اين يزوهش فاقد تامين كننده مالى بوده
مندرج در سند يا نوع يولى كه او به ناقل سند به خود داده است،

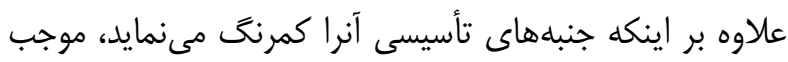

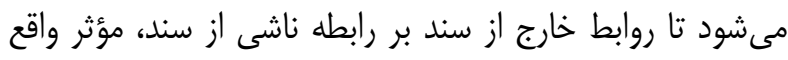
كرد.

\section{نتيجه}

مقررات مربوط به اسناد تجارى ايران در خصوص برقرارى

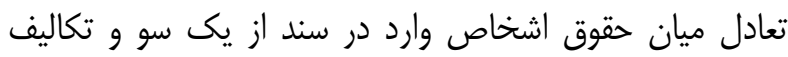

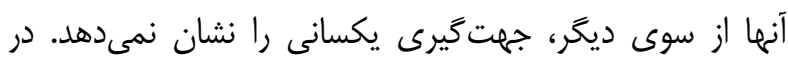

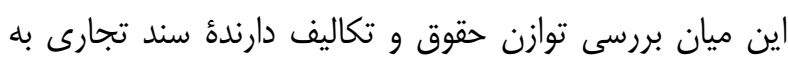
عنوان كسى كه ابتكار عمل در اختيار او قرار دارد، اين عدم يكنواختى را به صورت ير رنى تر هويدا مىنمايد: الف. علىرغم كهنكى بخش عمدة مقررات راجع به برات، سفته و קֶى، قانونگذار در موارد متعددى نشان داده است كه علاقمند به برقرارى تعادل ميان حقوق و تكاليف دارندة سند بوده و نمى خواهد امتياز يكطرفه يا تكليف بدون عوضى را نسبت به او لون

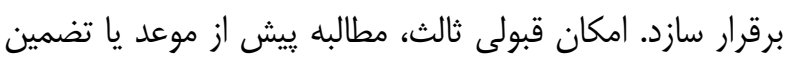

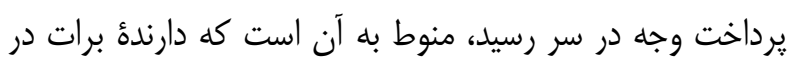
مهلت مقرر قانونى، نسبت به ارائه آن براى قبولى، اقدام نموده و در صورت نكول يا امتناع از قبول يا نكول در موعد مقرر،

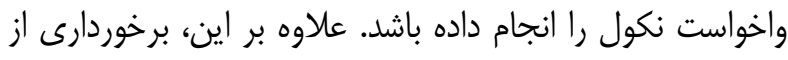

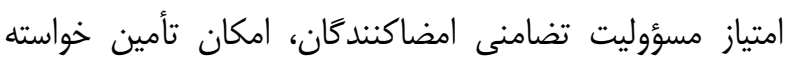

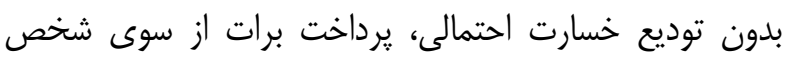

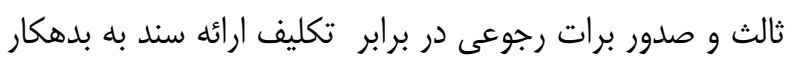
و مطالبه يرداخت وجه آن و در صورت عدم يرداخت، انجام رئر اعتراض عدم يرداخت، قبول يرداخت جزئى و اقدام از روى حسن نيّت، حسب مورد، قرار گرفتنه است.

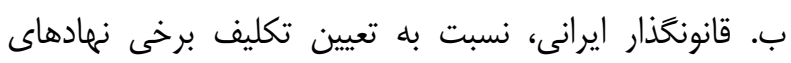
مدنى مخل به فلسفه وجودى حقوق اسناد تجارى، كوتاهى نموده و اين سكوت، عملاً خاصيّت ذاتى اسناد مذكور را خنثى حسنى نموده است تا جايى كه حتى عمل كردن به تمام وظايفى كه قانون براى دارنده سند مقرر نموده است، نمىتواند خوانده را در

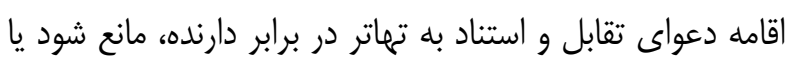


منابع و مآخذ

الف. منابع فارسى و عربى و ماحلى

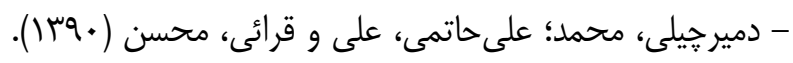

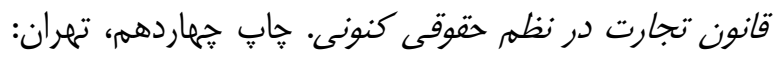

$$
\text { انتشارات دادستان. }
$$

- رسايىنيا، ناصر (سلسا). كلّيات حقوق بازركانى. تهران:

$$
\text { مؤسسّه انتشاراتى ويستار. }
$$

- ستوده تهرانى، حسن (MMM). حقوق تجارت. جلد سوم، خاب

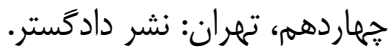

- سنهورى، عبدالززاق احمد (19M1). نظريه العقد. جلد اول،

$$
\text { بيروت،: منشورات الحلبى الحقوقيه. }
$$

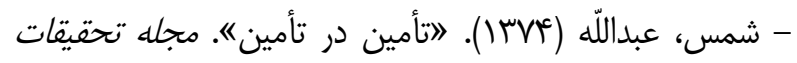

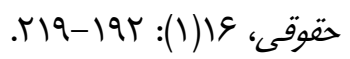

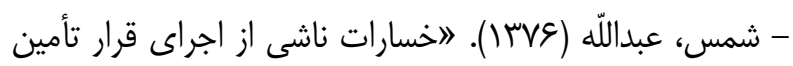

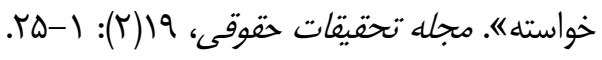

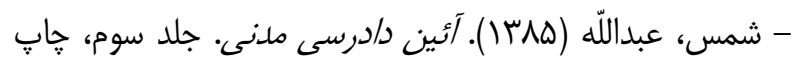

$$
\text { هفته، تهران: انتشارات دراك. }
$$

- شهيدى، مهدى (I) - (I). سقوط تعهدات. جاب جهارم، تهران:

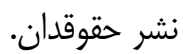

- شهيدى، مهلدى (1) (1). حقوق ملنى سه: تعهدات. خاب

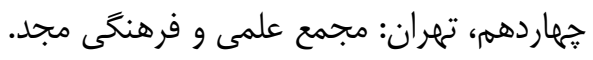

- صفايى، سيّد حسين (זيسا). دورة مقدّماتى حقوق ملنى.

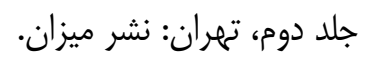

- صقرى، محمد (•^رب). حقوق بازركانى. جلد اول، تهران: شركت سمامى انتشار.

- صقرى، محمد (INYVI). حقوق بازركانى، اسناد، كزيلده

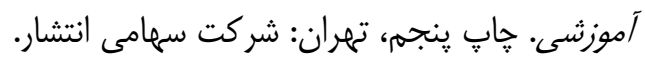

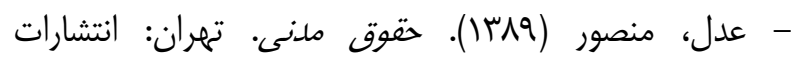

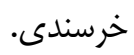

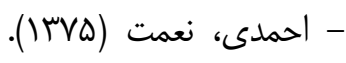
تهران: انتشارات اطلس. تعمد

- اخلاقى، بهروز (rYr)). جزوه درسى حقوق تجارت سه. تهران: انتشارات دانشكده حقوق و علوم سياسى دانى دانشعاه

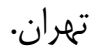

- اردبيلى، مولى احمد (IFV) الاذهان. جلد نهم، جاب سوم، قم: مؤسسه النشر الاسلامى.

- اسكينى، ربيعا (سץYI). حقوق تجارت تطبيقى. خاب اول، تهران: مجمع علمى فرهنكى مجد.

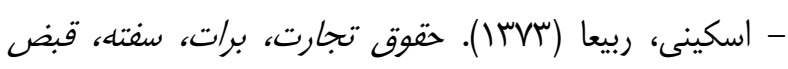

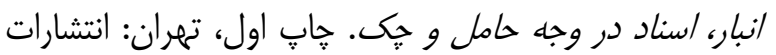

سمت.

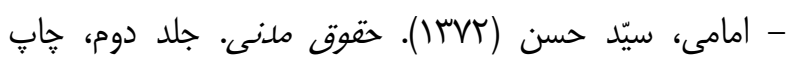
جهاردهم، تهران: كتابفروشى اسلاميّه.

- ثابت سعيدى، ارسلان (1) (1). حقوق بازركانى. خاب يازدهم،

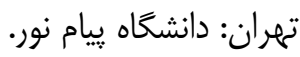

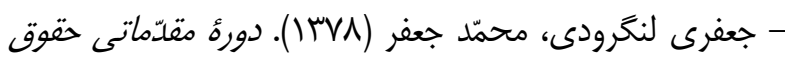
مدنى، حقوق تعمّدات. جاب سوم، تهران: انتشارات كنج دانش.

- جعفرى لنغرودى، محمد جعفر (IIV9). محشاى قانون ملنى.

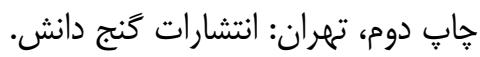

- جعفرى لنكرودى، محمد جعفر (MM (IM). دايره المعارف حقوق ملنى و تجارت. جلد اول، تهران: انتشارات كنج دانش.

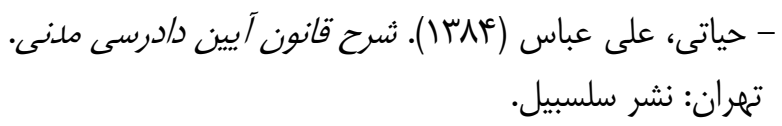
- خالقيان، جواد (هیץ ا). تأمين خسارت /حتمالى. تهران: نشر معاصر. - مان. - خزاعى، حسين (هیזّ). حقوق تجارت. جلد اول، خاب اول،

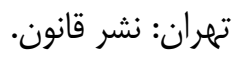


- ميرزايى، عليرضا (سلسا). مجموعه قوانين و مقررات حقوقى. جلد دوم، حابٍ اول، تهران: انتشارات بهنامى.

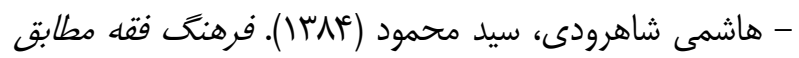

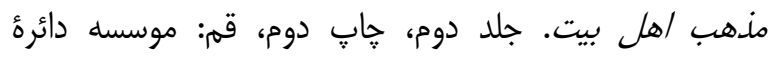
المعارف فقه اسلامى بر طبق مذهب اهل بيت.

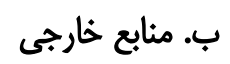

- Batra, V. K \& Kalra, N. K (1988). Mercantile Law. New Delhi: Tata McGrow Publishing.

- Keenan, S \& Keenan, S (1999). Advanced Business Law. $6^{\text {th }}$ ed. US: Pitman Publishing Ltd.

- Padfield, C.F \& Barker, D.L.A (1989). Law Made Simple. $7^{\text {th }}$ ed. London: Made Simple Books.
- فخارى، امير حسين (1) ع (IN). حقوق تجارت. تهران: مجمع

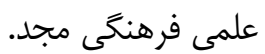

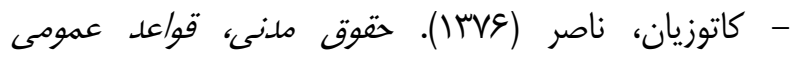
قراردادها. جلد جهارم، خاب دوم، تهران: شركت انتشار.

- كاتوزيان، ناصر (IrVV). حقوق ملنى، نظريه عمومى - /يقاع

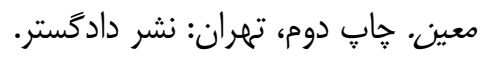

-كاتوزيان، ناصر (عمبر). عدالت قضايی. جاب سوم، تهران: بنياد حقوقى ميزان.

- كاتوزيان، ناصر (19 (1). نظريه عمومى تعهدات. جاب ششه،

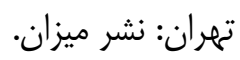

- كاويانى، كوروش (سیرا). حقوق اسناد تجارتى. تهران: نشر

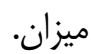

- كريمى، عبّاس (عمبا). آيين دادرسى ملنى. تهران: مجمع علمى فرهنگ مجى مجد. 


\section{References}

- Adl, M (2010). Civil law. Tehran: Khorsandi Publishing. (Persian)

- Ahmadi, N (1996). Civil Procedure. $1^{\text {st }}$ ed. Tehran: Atlas Publishing. (Persian)

- Akhlaghi, B (1993). Commercial Law. Tehran: Tehran University Faculty of Law Publishing. (Persian)

- Ardabili, A (2006). Majma Al-Borhan. Vol 9, $3^{\text {rd }}$ ed. Qum: Islamic Publishing Institute. (Arabic)

- Batra, V. K \& Kalra, N. K (1988). Mercantile Law. New Delhi: Tata McGrow Publishing.

- Damirchili, M; AliHatami, A \& Qaraei, M (2011). Commercial Law in Contemporary Legal Order. $14^{\text {th }}$ ed. Tehran: Dadsetan Publishing. (Persian)

- Emami, SH (1993). Civil Law. Vol 2, $14^{\text {th }}$ ed. Tehran: Eslami Library. (Persian)

- Eskini, R (1994). Commercial Law. $1^{\text {st }}$ ed. Tehran: Samt Publishing. (Persian)

- Eskini, R (1994). Comparative Commercial Law. $1^{\text {st }}$ ed. Tehran: Majd Publishing. (Persian)

- Fakhari, AH (2008). Commercial Law. Tehran: Majd Publishing. (Persian)

- Hashemi Shahroudi, SM (2005). Jurisprudence Encyclopedia. Vol 2, 2 ${ }^{\text {nd }}$ ed. Qum: Maaref Publishing. (Persian)

- Hayati, AA (2005). Commentary to Civil Procedure. Tehran: Salsabil Publishing. (Persian)

- Jafari Langroudi, MJ (1999). Elementary Civil Law. $3^{\text {rd }}$ ed. Tehran: Ganj Danesh Publishing. (Persian)

- Jafari Langroudi, MJ (2000). Commentary on Civil Law. $2^{\text {nd }}$ ed. Tehran: Ganj Danesh Publishing. (Persian)
- Jafari Langroudi, MJ (2009). Commercial and Civil Law Encyclopedia. Vol 1, Tehran: Ganj Danesh Publishing. (Persian)

- Karimi, A (2007). Civil Procedure. Tehran: Majd Publishing. (Persian)

- Katouzian, N (1997). Civil Law: General Rules of Contracts. Viol, $2^{\text {nd }}$ ed. Tehran: Enteshr Publishing. (Persian)

- Katouzian, N (1998). Civil Law: General Theory. $2^{\text {nd }}$ ed. Tehran: Dadgostar Publishing. (Persian)

- Katouzian, N (2007). Legal Justice. $3^{\text {rd }}$ ed. Tehran: Mizan Publishing. (Persian)

- Katouzian, N (2012). General Theory of Contracts. $6^{\text {th }}$ ed. Tehran: Mizan Publishing. (Persian)

- Kaviani, K (1383). The Law of Commercial Instruments. Tehran: Mizan Publishing. (Persian)

- Keenan, S \& Keenan, S (1999). Advanced Business Law. $6^{\text {th }}$ ed. US: Pitman Publishing Ltd.

- Khaleghian, J (2006). Probable Remedy. Tehran: Moaser Publishing. (Persian)

- Khazaei, H (2005). Commercial Law. Vol 1, $1^{\text {st }}$ ed. Tehran: Ghanoon Publishing. (Persian)

- Mirzaei, AR (1994). Laws and Provisions Complex. Vol 2, $1^{\text {st }}$ ed. Tehran: Behnami Publishing. (Persian)

- Padfield, C.F \& Barker, D.L.A (1989). Law Made Simple. $7^{\text {th }}$ ed. London: Made Simple Books.

- Rasaei Nia, N (1998). Trade law. Tehran: Vistar Publishing. (Persian) 
- Sabet Saeedi, A (2010). Trade Law. $11^{\text {th }}$ ed. Tehran: Payame Noor University Publishing. (Persian)

- Safaei, SH (2003). Elementary Civil Law. Vol 2, Tehran: Mizan Publishing. (Persian)

- Sanhouri, A (1988). The Theory of Contract. Vol 1, Beirut: Hoghogh Publishing. (Arabic)

- Saqari, M (2001). Commercial Law. Vol 1, Tehran: Enteshar Publishing. (Persian)

- Saqari, M (2008). Selections of Commercial Law. $5^{\text {th }}$ ed. Tehran: Enteshar Publishing. (Persian)

- Shahidi, M (2008). Termination of Obligation. $14^{\text {th }}$ ed. Tehran: Hoghoghdan Publishing. (Persian)

- Shahidi, M (2010). Civil Law: Obligations. $14^{\text {th }}$ ed. Tehran: Majd Publication. (Persian)

- Shams, A (1995). "Bail in Bail". Legal research Journal, 16(1): 192-219. (Persian)

- Shams, A (1996). "Loses of Performing Garnishee". Legal research Journal, 19(2): 125. (Persian)
- Shams, A (2006). Civil Procedure. Vol 3, $7^{\text {th }}$ ed. Tehran: Derak Publishing. (Persian)

- Sotoudeh Tehrani, H (2009). Commercial Law. Vol 3, $14^{\text {th }}$ ed. Tehran: Dadgostar Publishing. (Persian) 